\title{
Nitrogen oxides in the boundary layer and free troposphere at the Mt. Bachelor Observatory
}

\author{
D. R. Reidmiller ${ }^{1}$, D. A. Jaffe ${ }^{2}$, E. V. Fischer ${ }^{1}$, and B. Finley ${ }^{2}$ \\ ${ }^{1}$ Department of Atmospheric Sciences, University of Washington, Seattle, WA, USA \\ ${ }^{2}$ Science \& Technology Program, University of Washington-Bothell, Bothell, WA, USA \\ Received: 12 February 2010 - Published in Atmos. Chem. Phys. Discuss.: 26 February 2010 \\ Revised: 18 June 2010 - Accepted: 28 June 2010 - Published: 6 July 2010
}

\begin{abstract}
Nitrogen oxide $\left(\mathrm{NO}_{\mathrm{x}}=\mathrm{NO}+\mathrm{NO}_{2}\right)$ observations were made at the Mt. Bachelor Observatory in central Oregon, USA (MBO; $2.73 \mathrm{~km}$ above sea level) during one autumn and three springtime (15 April-20 May) periods. This is the first study to discuss interannual variability in $\mathrm{NO}_{\mathrm{x}}$ for this region. $\mathrm{NO}_{\mathrm{x}}$ concentrations (mean $\pm 1 \sigma$ ) for spring 2007, 2008 and 2009 were $119 \pm 65,117 \pm 65$, and $91 \pm 54$ pptv, respectively. The difference in mean mixing ratios between 2007 and 2008 is not statistically significant, whereas the difference between these years and 2009 is significant $(p<$ 0.01). We attribute the decline in $\mathrm{NO}_{\mathrm{x}}$ from 2007-2008 to 2009 to changes in free tropospheric synoptic conditions over the Northeast Pacific and trans-Pacific transport pathways during spring 2009. In 2009, there were: (1) higher geopotential heights over the Gulf of Alaska, (2) warmer temperatures over the Aleutian Islands/Gulf of Alaska and (3) much weaker winds throughout the North Pacific. During the autumn 2008 campaign, $\mathrm{NO}_{\mathrm{x}}$ concentrations (mean $\pm 1 \sigma$ ) were $175 \pm 548$ pptv. The highly non-normal distribution of data (skewness coefficient of 19.1 vs. 2.5, 2.8 and 2.4 in spring 2007, 2008 and 2009, respectively) resulted from periods of very high $\mathrm{NO}_{\mathrm{x}}$ levels. Using MODIS Rapid Response (Aqua and Terra) results, we show that during autumn our site can be heavily influenced by wildfires in western North America. This is in contrast to springtime, when the smaller positive (i.e., right) tail of the $\mathrm{NO}_{\mathrm{x}}$ distribution is driven largely by Asian long-range transport (ALRT) events.

We developed a novel means of segregating boundary layer (BL)-influenced vs. free tropospheric (FT) air. During spring 2008 we collected "chairlift soundings" of tem-
\end{abstract}

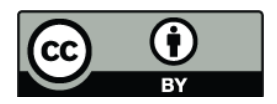

Correspondence to: D. Reidmiller (dreidm@atmos.washington.edu) perature, relative humidity and pressure in an effort to better understand the diurnal pattern of a BL influence at our summit station. Results from this experiment revealed that, on average, a BL influence begins around 10:00 PDT (UTC 07:00 h) in spring. Using this information to isolate FT air, we characterize probable pollution sources and synoptic conditions for the top $20 \mathrm{FT} \mathrm{NO}_{\mathrm{x}}$ events over three spring campaigns. Half $(n=10)$ of these 20 events were determined to be "Imported" events characterized by anomalously: (1) high geopotential heights off the west coast of North America, (2) warm temperatures stretching from the Aleutian Islands to Baja California, and (3) strong southwesterly winds in the Asian outflow region. Five events exhibited an influence from the North American continent. These events are characterized by very strong cyclonic behavior off the northwestern USA coast.

\section{Introduction}

$\mathrm{NO}_{\mathrm{x}}\left(=\mathrm{NO}+\mathrm{NO}_{2}\right)$ is an important tropospheric constituent because of its role in the production and loss of $\mathrm{O}_{3}$, regulation of $\mathrm{OH}$ radicals and formation of acid rain. In the lower troposphere, $\mathrm{NO}_{\mathrm{x}}$ sources are mostly anthropogenic, resulting from the combustion of fossil fuels. However, biomass burning and microbial emissions in soils can be large natural contributors in non-urban regions (van der A et al., 2008). Aircraft emissions provide fresh anthropogenic $\mathrm{NO}_{\mathrm{x}}$ in the upper troposphere, while lightning can produce large amounts of $\mathrm{NO}_{\mathrm{x}}$ in regions where deep convection is present.

The atmospheric lifetime of $\mathrm{NO}_{\mathrm{x}}$ can vary depending on the photochemical environment, but is typically on the order of hours to a day (Seinfeld and Pandis, 1998). Given

Published by Copernicus Publications on behalf of the European Geosciences Union. 
this relatively short lifetime and the fact that $\mathrm{NO}_{\mathrm{x}}$ sources are highly concentrated in urban centers, there is substantial heterogeneity in the distribution of $\mathrm{NO}_{\mathrm{x}}$ at the surface. Similarly, since the majority of $\mathrm{NO}_{\mathrm{x}}$ sources are confined to the surface layer and its lifetime is short, there is a very strong vertical gradient in $\mathrm{NO}_{\mathrm{x}}$ with concentrations peaking in the boundary layer (BL) and typically reaching a minimum in the free troposphere (FT) (Seinfeld and Pandis, 1998). These characteristics of $\mathrm{NO}_{\mathrm{x}}$ make it a difficult compound to simulate accurately in chemical transport models (Thakur et al., 1999).

By largely controlling the abundance of $\mathrm{O}_{3}$, total reactive nitrogen $\left(\mathrm{NO}_{\mathrm{y}}\right)$ plays a critical role in the overall oxidizing capacity of the troposphere. In particular, the partitioning of $\mathrm{NO}_{\mathrm{y}}$ evolves during the emission, export and long-range transport of pollution. Far from emission sources, $\mathrm{NO}_{\mathrm{y}}$ in the FT is typically composed primarily of $\mathrm{HNO}_{3}$ and peroxyacetyl nitrate, or PAN (Koike et al., 1996; Kondo et al., 1997). The relative amounts of $\mathrm{NO}_{\mathrm{x}}$ vs. other $\mathrm{NO}_{\mathrm{y}}$ reservoir species is a strong function of temperature, oxidant concentrations and the distribution and abundance of volatile organic compounds (VOC). If there is substantial PAN decomposition, the resulting $\mathrm{NO}_{\mathrm{x}}$ can lead to $\mathrm{O}_{3}$ production in regions far downwind from pollution sources (Kotchenruther et al., 2001a; Hudman et al., 2004; Zhang et al., 2008; Fischer et al., 2010).

Emissions inventories and satellite observations have revealed a dramatic increase in $\mathrm{NO}_{\mathrm{x}}$ emissions in the developing world, particularly in South and East Asia (Richter et al., 2005; Ohara et al., 2007; Zhang et al., 2008). The most pronounced growth in $\mathrm{NO}_{\mathrm{x}}$ emissions has occurred in Eastern China (van der A et al., 2008), making the study of pollution export, its evolution during long-range transport (Bertram, 2006) and its downwind air quality impacts from this region of particular interest (Reidmiller et al., 2009a; Cooper et al., 2010).

During the long-range transport of Asian pollution to North America, which peaks in spring (e.g., Jaffe et al., 1999), Koike et al. (2003) show that $30-40 \%$ of $\mathrm{NO}_{\mathrm{y}}$ released in the Chinese BL is transported to the Western Pacific atmosphere between $0-7 \mathrm{~km}$. Of this $\mathrm{NO}_{\mathrm{y}}$, only a very small fraction $(\sim 0.5 \%)$ remains as $\mathrm{NO}_{\mathrm{x}}$; most of the $\mathrm{NO}_{\mathrm{y}}$ is in the form of either PAN or $\mathrm{HNO}_{3}$. In the FT over the Pacific Ocean, much of the $\mathrm{HNO}_{3}$ is deposited/scavenged, leaving PAN as the primary $\mathrm{NO}_{\mathrm{y}}$ reservoir for the original Asian $\mathrm{NO}_{\mathrm{x}}$ emissions (Bertram, 2006). Since the lifetime of PAN is temperature-dependent, a springtime climatological region of subsidence off the west coast of North America facilitates the release of $\mathrm{NO}_{\mathrm{x}}$ from the thermal decomposition of PAN. This leads to net $\mathrm{O}_{3}$ production in an otherwise minimally polluted environment (Kotchenruther et al., 2001a; Hudman et al., 2004; Zhang et al., 2008).

\section{Utilizing mountain-top trace gas observations}

Trace gas measurements in the FT are far less abundant than those in the BL. However, such observations are essential to fully understand chemical processes and transformations occurring during long-range transport. Furthermore, mountaintop observations in the FT serve a vital role in testing chemical transport models (Thakur et al., 1999), which in turn provide the basis for many a priori satellite retrievals (Martin et al., 2003; Emmons et al., 2007). In particular, $\mathrm{NO}_{\mathrm{x}}$ observations in the FT are important because the reduced specific humidity and surface loss processes inhibit $\mathrm{O}_{3}$ destruction which, when coupled with low $\mathrm{NO}_{\mathrm{x}}$ levels found in the remote $\mathrm{FT}$, results in more efficient photochemical $\mathrm{O}_{3}$ production aloft (Carpenter et al., 2000).

However, great care must be exercised in interpreting observations from a mountain-top site. Diurnal and seasonal changes in the local flows (upslope vs. downslope winds) can bring varying degrees of BL-influenced air to a station as high as $4 \mathrm{~km}$ above sea level, a.s.l. (Forrer et al., 2000; Kleissl, et al., 2007). We use observations from the Mt. Bachelor Observatory, MBO $\left(43.979^{\circ} \mathrm{N}, 121.687^{\circ} \mathrm{W}\right.$; $2.73 \mathrm{~km}$ a.s.1.) to better understand the diurnal changes in upslope vs. downslope flows at mountaintop observatories.

Measurements from MBO have led to a several new discoveries. Jaffe et al. (2005) determined that the $\mathrm{Hg} / \mathrm{CO}$ ratio can be used as a chemical signature for ALRT pollution plumes as we discuss in Sect. 3.5. Weiss-Penzias et al. $(2006,2007)$ extended this analysis to quantify the influence of Asian and biomass burning emissions at MBO. Swartzendruber et al. (2006) revealed that FT air tends to have large amounts of reactive gaseous mercury whereas wet, BL-influenced air tends to have far less of this form of $\mathrm{Hg}$. Wolfe et al. (2007) measured acyl peroxy nitrates to detect ALRT plumes during the INTEX-B campaign. Reidmiller et al. (2009b) compared the interannual variability of ALRT events at MBO from spring 2005 to spring 2006 using the LRT3 index (Liang et al., 2005) that we use here in Sect. 3.4. Finley et al. (2009) quantified the amount of particulate mercury emitted from regional (Pacific Northwest) wildfires and found that it amounts to $15 \%$ of the total mercury emitted from these fires. Fischer et al. (2010) measured peroxyacetyl nitrate (PAN) at MBO during spring 2008 and characterized the synoptic conditions and $\mathrm{O}_{3}$ production in several ALRT plumes with results relevant to our findings in Sect. 3.5. This study seeks to add to the expanding role MBO plays in better understanding atmospheric chemistry in the FT.

Given this context, we sought to answer the following questions using data from one autumn (28 August-9 October 2008) and three spring (15 April-20 May) campaigns:

(1) How does the BL influence at the summit of Mt. Bachelor (2.73 km a.s.l.) evolve diurnally and over the course of a typical spring measurement season? 
(2) What is the range of $\mathrm{NO}_{\mathrm{x}}$ levels in the FT and $\mathrm{BL}$ at Mt. Bachelor, and how do these differ in spring vs. autumn?

(3) During the three springtime campaigns, was there significant interannual variability in mean $\mathrm{NO}_{\mathrm{x}}$ mixing ratios at Mt. Bachelor? If so, what was the cause?

(4) How do FT $\mathrm{NO}_{\mathrm{x}}$ mixing ratios at Mt. Bachelor compare to values measured at other mid-latitude mountain-top sites and in Asia-Pacific aircraft campaigns?

(5) What synoptic conditions bring the greatest $\mathrm{FT} \mathrm{NO}_{\mathrm{x}}$ concentrations to Mt. Bachelor?

To explore (1), we developed a novel means of tracking the evolution of meteorological parameters along the top $\sim 500 \mathrm{~m}$ of the mountain via "chairlift soundings" as described in Sect. 2.3.2. A data segregation technique developed from the sounding data, coupled with synoptic characterizations from National Center for Environmental Prediction/National Center for Atmospheric Research (NCEP/NCAR, http://www.esrl.noaa.gov/psd/data/ composites/day/) reanalysis allow us to unravel (2) and (3), as presented in Sects. 3.1, 3.4, and 3.5. Thorough review of the literature provided a detailed database from which we could answer (4) in Sect. 3.3. Question (5) is explored in Sect. 3.5 by using HYSPLIT backtrajectories to identify probable pollution source regions for these high $\mathrm{FT} \mathrm{NO}_{\mathrm{x}}$ events. NCEP reanalysis was then used to characterize the synoptic conditions that brought about these events.

\section{Methodology}

\subsection{Site description}

The Mt. Bachelor Observatory, MBO $\left(43.979^{\circ} \mathrm{N}\right.$, $121.687^{\circ} \mathrm{W} ; 2.73 \mathrm{~km}$ a.s.1.) was established in 2004 atop a dormant volcano in central Oregon in the northwestern USA (Fig. 1a). Many studies have used data from MBO to understand the long-range transport of Asian pollution to North America (Jaffe et al., 2005; Weiss-Penzias et al., 2006, 2007; Wolfe et al., 2007; Strode et al., 2008; Zhang et al., 2008, 2009; Fischer et al., 2010; Reidmiller et al., 2009b; Fischer and Jaffe, 2010). Mt. Bachelor is home to a ski resort with all electric ski lifts (Fig. 1b). The only emissions at the summit are due to the occasional passes of snow-grooming equipment. Contamination from these groomers is easily identified by spikes in $\mathrm{NO}_{\mathrm{x}}, \mathrm{CO}$ and the aerosol absorption coefficient, and these periods have been removed from the data used in this analysis. The nearest populated areas are Bend, Oregon (pop. 65 210), $31 \mathrm{~km}$ to the east and Redmond, Oregon (pop. 21109 ), $53 \mathrm{~km}$ to the northeast. Winds at the summit usually have a strong westerly component, so it is rare that anthropogenic pollution from either town reaches the station. Eugene, Oregon (pop. 142 180) is $140 \mathrm{~km}$ west
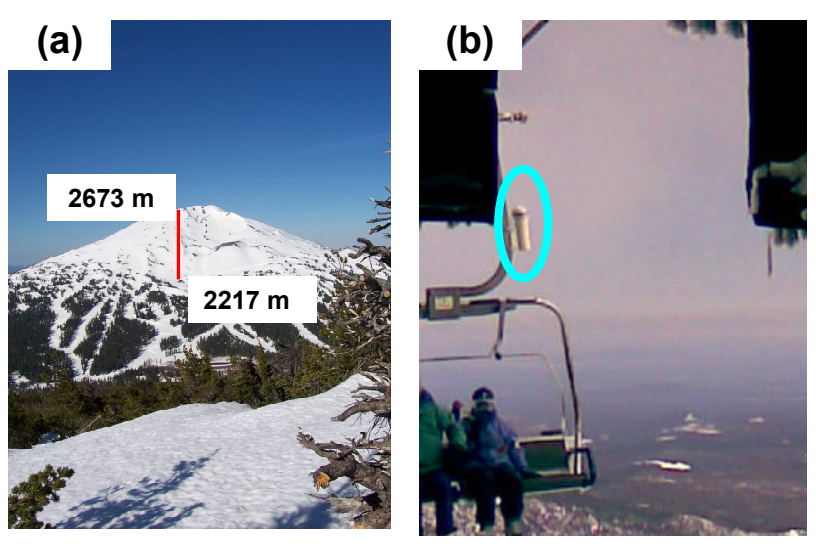

Fig. 1. (a) Mt. Bachelor; observatory is at summit, with the chairlift used in the soundings highlighted in red $(2217 \mathrm{~m}$ up to $2673 \mathrm{~m}$ a.s.1.); (b) HOBO MicroStation instrument collecting "chairlift soundings".

and is the only major population center between MBO and the Pacific coast.

Trace gas species including $\mathrm{O}_{3}, \mathrm{CO}$, speciated $\mathrm{Hg}$, and aerosol optical properties have been measured since 2004 along with a standard suite of meteorological parameters including temperature, relative humidity, wind speed and direction and ambient pressure (e.g., Weiss-Penzias et al., 2006; Swartzendruber et al., 2006; Wolfe et al., 2007). $\mathrm{NO}_{\mathrm{x}}$ and PAN observations began in 2007. The sampling inlet for gaseous measurements is 5/8" OD PFA tubing and is located $\sim 15 \mathrm{~m}$ above the instrument room and $4 \mathrm{~m}$ above the roof of the building. Ambient air is drawn through a $1 \mu \mathrm{m}$ Teflon filter and into a Teflon gas distribution manifold at a rate of $\sim 20 \mathrm{Lpm}$, resulting in a residence time of $\sim 2 \mathrm{~s}$. All trace gas measurement systems are connected to this manifold, except the $\mathrm{Hg}$ instrumentation, which has its own specially-designed inlet (Swartzendruber et al., 2006). The sampling of aerosols is described elsewhere (Weiss-Penzias et al., 2006, 2007; Fischer and Jaffe, 2010). All times are listed as Pacific Daylight Time (PDT=UTC $-07: 00 \mathrm{~h}$ ), unless otherwise noted. All statistics are listed as mean \pm 1 standard deviation $(\sigma)$, unless otherwise noted.

\section{$2.2 \mathrm{NO}_{\mathrm{x}}$ measurements}

\subsubsection{Instrument design}

Nitrogen oxides ( $\mathrm{NO}$ and $\mathrm{NO}_{2}$ ) were measured using a two-channel chemiluminescence instrument manufactured by Air Quality Design, Inc. (Colorado, USA, http://www. airqualitydesign.com/). The technique of chemiluminescence for detection of atmospheric $\mathrm{NO}_{\mathrm{x}}$ has been wellestablished and evaluated (e.g., Drummond et al., 1985; Carroll et al., 1985). A detailed description of the system, its calibration and a detailed error analysis is given by 
Reidmiller (2010). We briefly describe the unique attributes of our system here.

Ambient air is pulled into the $\mathrm{NO}_{\mathrm{x}}$ system as described in the previous Section. The airflow is split into an NO channel and a $\mathrm{NO}_{\mathrm{x}}$ channel $\left(\mathrm{NO}_{2}\right.$ is measured differentially via this channel, so henceforth we refer to this as the $\mathrm{NO}_{2}$ channel). During the measure mode, a large excess of $\mathrm{O}_{3}$ is introduced into the ambient airflow in a cylindrical reaction chamber immediately in front of a red-infrared-sensing photomultiplier tube (PMT). Excess $\mathrm{O}_{3}$ is created by running $100 \mathrm{~cm}^{3} / \mathrm{min}$ of high purity $\mathrm{O}_{2}$ through a high voltage discharge tube which is then added to the ambient air sample stream. To zero the system (which is done every $5 \mathrm{~min}$ after a 5 min measure cycle), the excess $\mathrm{O}_{3}$ is injected into a "zeroing volume" where it reacts with the ambient air upstream of the PMT, thereby preventing any photon detection. Since most interference reactions are slower than the $\mathrm{NO}+\mathrm{O}_{3}$ reaction (which produces an excited state $\mathrm{NO}_{2}$ molecule, $\mathrm{NO}_{2}^{*}$ ), the signal detected when $\mathrm{O}_{3}$ is injected into this zeroing volume can be subtracted from the signal measured when the $\mathrm{O}_{3}$ is added directly to the reaction chamber, resulting in a signal from the $\mathrm{NO}_{2}^{*}$ to $\mathrm{NO}$ chemiluminescence alone (Lee et al., 2009). A red filter is used to eliminate photons from chemiluminescence at shorter wavelengths.

Detection of $\mathrm{NO}_{2}$ occurs as $\mathrm{NO}$ following photolysis in the ultraviolet range using a Blue Light $\mathrm{NO}_{2}$ Converter (BLC, Air Quality Design, http://www.airqualitydesign. com). Buhr (2004) describes the $\mathrm{NO}_{2}$ converter design and initial testing with results showing it performs better than previous models of $\mathrm{NO}_{2}$ converters. Lee et al. (2009) discuss its successful deployment at the Cape Verde Observatory. The BLC has a $17 \mathrm{~mL}$ photolysis chamber, which allows a $1 \mathrm{~s}$ residence time at a flow of $1 \mathrm{sLpm}$. On either end of this reaction chamber is a series of light emitting diode (LED) arrays which produce UV radiation between $385-405 \mathrm{~nm}$. Using a UV light source (versus traditional thermal converters) provides the advantage of specifically converting $\mathrm{NO}_{2}$ and not $\mathrm{HNO}_{3}$, PAN or other $\mathrm{NO}_{\mathrm{y}}$ species. Furthermore, the LED-based method employed by the BLC avoids heating the sample significantly, which eliminates the production of $\mathrm{NO}_{2}$ from the thermal decomposition of PAN.

\subsubsection{Instrument calibrations}

Standard addition calibrations are conducted automatically every six hours and consist of 10 cycles. The first four $5 \mathrm{~min}$ cycles involve zeroing the system by adding the NO calibration gas to the $\mathrm{NO}$ or $\mathrm{NO}_{2}$ channels with and without a UV Pen-ray lamp activated. This UV lamp produces $\mathrm{O}_{3}$ from hydrocarbon-free air for the gas phase titration of $\mathrm{NO}$ to $\mathrm{NO}_{2}$. This allows for an instrument calibration of $\mathrm{NO}_{2}$. These cycles add the excess $\mathrm{O}_{3}$ upstream of the reaction volumes. The next two cycles are the typical $5 \mathrm{~min}$ zero and measure modes. In the final four calibration cycles, the NO calibration gas goes through the same four cycles as for the zeroing part of the calibration cycle, except this time the excess $\mathrm{O}_{3}$ is injected directly into the reaction volumes (with 2-3 min added for equilibration).

The zeroing efficiency in both channels remained above 0.98 for all four measurement seasons $(1.000 \pm 0.003$ and $0.999 \pm 0.006$ for the $\mathrm{NO}$ and $\mathrm{NO}_{2}$ channels, respectively). The $\mathrm{NO}$ sensitivity in the $\mathrm{NO}$ channel was $3.4 \pm 0.3$ counts/pptv. The $\mathrm{NO}$ sensitivity in the $\mathrm{NO}_{2}$ channel was $2.9 \pm 0.4$ counts/pptv; the $\mathrm{NO}_{2}$ sensitivity in the $\mathrm{NO}_{2}$ channel was $1.6 \pm 0.4$ counts/pptv. The minimum values in all these statistics were recorded during times when one of the ozone generators was under repair. When one of the two $\mathrm{O}_{3}$ generators is under repair, $\mathrm{O}_{3}$ is still being provided to the system, but at about half the concentration as when both $\mathrm{O}_{3}$ generators are operating normally. As a result, the instrument sensitivity is at a minimum when less $\mathrm{O}_{3}$ is available for the chemiluminescent reaction necessary for the detection of $\mathrm{NO}$ mixing ratios. The $\mathrm{NO}_{2}$ conversion efficiency was $0.54 \pm 0.11$, on par with values from other groups using the $\mathrm{BLC} \mathrm{NO}_{2}$ converter (M. Buhr, personal communication, 2009). The 5 min $\mathrm{NO}$ and $\mathrm{NO}_{2}$ detection limits were $4 \pm 1$ and $10 \pm 3$ pptv, respectively, where detection limit is defined as $3 \times$ the standard deviation of a blank measurement (Winefordener and Long, 1983; Keith, 1991). The derivation of detection limits and other instrument statistics is provided by Reidmiller (2010). These $\mathrm{NO}_{\mathrm{x}}$ instrument statistics are presented in supplemental Fig. 1. Detection limits were strongly correlated with the instrument room temperature, lowest when temperatures were at a minimum. Precision in both channels was found to be $1-2$ pptv for hourly averaged data (Reidmiller, 2010).

\subsubsection{Error analysis}

To assess our system's uncertainty, we must account for the systematic errors occurring during calibration cycles and in determining artifacts. By propagating these precision and accuracy errors, we can reach an estimate for the overall uncertainty in our NO observations. The NO accuracy was calculated from the uncertainties, following the method of Lee et al. (2009):

(1) $\pm 1 \%$ each: sample and calibration gas mass flow controllers, as stated by the manufacturer (MKS Instruments, http://www.mksinst.com) and confirmed with lab tests using an Agilent Optiflow 420 flowmeter,

(2) $\pm 2 \%$ : concentration of USA National Institute of Standards and Technology (NIST) - traceable NO calibration standard, provided by Scott-Marrin or Airgas (depending on year). Both suppliers certify that the NO in $\mathrm{N}_{2}$ mixture is stable for 2 years,

(3) artifact error, described in detail by Reidmiller (2010) and briefly summarized below. 
Since we expect nighttime NO values to be zero at a site such as $\mathrm{MBO}$, we can use any deviation from $[\mathrm{NO}]=0$ to quantify any NO artifact. These artifact values were then subtracted from the NO data (and linearly interpolated night-to-night) to provide a "true" ambient NO concentration. NO artifacts averaged over the four seasons presented here were $6 \pm 4$ pptv. This $\sigma$ (4 pptv) is then used to determine the overall measurement uncertainty. The root mean square of the accuracy and precision errors give a total uncertainty for daytime $\mathrm{NO}$ observations of $39 \%$ at 5 pptv and $20 \%$ at $10 \mathrm{pptv}$, for the hourly averaged data.

$\mathrm{NO}_{2}$ is not zero at night; therefore, we determined the $\mathrm{NO}_{2}$ artifact in the lab using breathing air as the sample air with a series of scrubbers filled with a mixture of activated charcoal and $\mathrm{KMnO}_{4}$ at the inlet. The measured $\mathrm{NO}_{2}$ artifact over $6 \mathrm{~h}$ in the lab was $9 \pm 2$ pptv. While it is possible that some of this $\mathrm{NO}_{2}$ remained in our zero air, following Lee et al. (2009), we place a conservative estimate on the $\mathrm{NO}_{2}$ artifact of \pm 9 pptv. This combined with the extra uncertainty in the conversion of $\mathrm{NO}_{2}$ to $\mathrm{NO}$, means that the overall uncertainty for $\mathrm{NO}_{2}$ measurements is $30 \%$ at $20 \mathrm{pptv}$ and $14 \%$ at $60 \mathrm{pptv}$ (for hourly averaged data).

\subsection{Boundary Layer (BL) vs. Free Tropospheric (FT) segregation of data}

\subsubsection{Previous efforts}

Previous studies have recognized that trace gas data from mountaintop sites need to be segregated to isolate FT (downslope) air from BL (upslope)-influenced air. Fahey et al. (1986), Wang et al. (2006) and Murphy et al. (2006) have all used a simple time-of-day classification to identify FT air at their Niwot Ridge (Colorado, USA), Mt. Waliguan (China) and Big Hill (California, USA) sites, respectively. Parrish et al. (1990) expanded the method of Fahey et al. (1986) to combine a time-of-day segregation with wind direction to eliminate times when outflow from the Denver metropolitan area impacted observations at their Niwot Ridge site. Researchers at the Pico Mountain site on the Azores in the central Atlantic have used both a time-of-day technique coupled with critical values of $\mathrm{NO}_{\mathrm{x}}$ and $\mathrm{NO}_{\mathrm{y}}$ to isolate FT air (Val Martin et al., 2008a). Kleissl et al. (2007) conducted a detailed dynamical modeling experiment along with calculations of stability parameter, vertical velocity, water vapor and various trace gases to determine the fraction of time when buoyant upslope flows influenced measurements at the Pico Mountain summit. The Jungfraujoch site in the Swiss Alps has published the most extensive studies on isolating FT or "background" air. Zellweger et al. (2000) used synoptic classifications alongside wind direction and aerosol concentrations to remove any BL-influenced periods. To select FT days, Zanis et al. (2000) used times when there were no clouds, winds $>5 \mathrm{~m} / \mathrm{s}$, daily mean $\mathrm{CO}<200 \mathrm{ppbv}$, daily mean $\mathrm{NO}_{\mathrm{x}} / \mathrm{NO}_{\mathrm{y}}<0.3$ and daily mean condensation nuclei
$<800 \mathrm{~cm}^{-3}$. They also used a less stringent filtering to exclude data when: (a) the daytime (08:00-20:00 UTC) mean $[\mathrm{NO}]>60 \mathrm{pptv}$ and (b) the daily mean global radiation was lower than the campaign's median value. To identify FT air at Jungfraujoch, Zellweger et al. (2003) performed a detailed synoptic classification to remove: (a) föhn events, (b) periods of synoptic lifting and (c) times when there was thermallyinduced vertical transport. Balzani Lööv et al. (2008) used backtrajectories and meteorological statistics to develop a means of retrieving "background concentrations" of various trace gas observations at Jungfraujoch.

All these methods have proven to be quite useful, but they are also very site-specific. At MBO, we have used several segregation techniques to date. The most popular has been a segregation of the data by specific humidity. Weiss-Penzias et al. (2006) and Fischer et al. (2010) use percentiles of specific humidity to identify FT vs. BL-influenced air. These same studies also used specific humidity calculated from the 00:00 UTC and 12:00 UTC National Weather Service soundings from Medford, Oregon (MFR: $42.3^{\circ} \mathrm{N} 122.8^{\circ} \mathrm{W}$ ) and Salem, Oregon $\left(45.0^{\circ} \mathrm{N} 123.0^{\circ} \mathrm{W}\right)$ to determine a "representative altitude" for the air sampled at MBO. This technique can be misleading, however, as both these sites are on the windward side of the Cascade Range, whereas MBO is on the lee side. As a result, a thorough characterization of atmospheric stability over and downwind of the crest of the Cascades is essential to employ the sounding data correctly.

\subsubsection{Chairlift soundings}

Since there are no routine soundings within several hundred $\mathrm{km}$ of MBO on the lee side of the Cascades, we used a novel and opportunistic method to acquire in-situ vertical profiles of pressure, temperature $(T)$ and relative humidity $(\mathrm{RH})$ along the northwest face of the mountain during spring 2008. We employed a HOBO (http://www.onsetcomp.com/) Model \# S-THA-M002 T/RH sensor, Model \# S-BPA-CM10 barometric pressure sensor and a Model \# H21-002 Micro Station (to $\log$ the $1 \mathrm{~s}$ data). These components were sheltered in a custom-made PVC housing, specifically designed to allow ample airflow to pass over the sensors, ensuring quick response times (Fig. 1b). The $\sim 0.5 \mathrm{~m}$ housing was attached to the back of a chair on the ski resort's chairlift that runs from mid-mountain ( $\sim 2217 \mathrm{~m}$ a.s.l.) to the summit ( $\sim 2730$ m a.s.1.) where our trace gas species are measured (Fig. 1a). Using barometric pressure as a proxy for altitude, we were able to track the temporal evolution of the BL influence on the summit from early morning ( 08:00 PDT) until early afternoon ( $\sim$ 13:00 PDT) on eight separate days during spring 2008. Collecting these observations on eight distinct occasions over a 6-week period facilitates a study of the BL evolution under a variety of meteorological conditions. 
Table 1. Summary of $\mathrm{NO}_{\mathrm{x}}\left(=\mathrm{NO}+\mathrm{NO}_{2}\right)$ data for all four seasons presented in this paper. "Day" is defined as $5 \mathrm{~h}$ after sunrise through $1 \mathrm{~h}$ after sunset and "Night" is defined as $5 \mathrm{~h}$ after sunset through $1 \mathrm{~h}$ after sunrise (see Sect. 3.2). Note the large decline in $\mathrm{NO}_{\mathrm{x}}$ from spring 2007 and 2008 to spring 2009. Also note that mean $\mathrm{NO}_{\mathrm{x}}$ levels during the autumn campaign are significantly greater than during the spring campaigns.

\begin{tabular}{llrrrrrr}
\hline & & \multicolumn{2}{c}{ NO (in pptv) } & \multicolumn{2}{c}{ NO $_{2}$ (in pptv) } & \multicolumn{2}{c}{ NO (in pptv) } \\
& & Mean $\pm 1 \sigma$ & Median & Mean $\pm 1 \sigma$ & Median & Mean $\pm 1 \sigma$ & Median \\
\hline \multirow{5}{*}{ Spring 2006 } & ALL & $16 \pm 19$ & 6 & N/A & N/A & N/A & N/A \\
& Day & $23 \pm 22$ & 19 & N/A & N/A & N/A & N/A \\
& Night & $5 \pm 8$ & 2 & N/A & N/A & N/A & N/A \\
& ALL & $14 \pm 17$ & 6 & $105 \pm 62$ & 88 & $119 \pm 65$ & 101 \\
Spring 2007 & Day & $25 \pm 20$ & 20 & $106 \pm 61$ & 91 & $131 \pm 68$ & 112 \\
& Night & $4 \pm 6$ & 2 & $102 \pm 56$ & 86 & $106 \pm 57$ & 89 \\
& ALL & $18 \pm 26$ & 8 & $99 \pm 55$ & 85 & $117 \pm 65$ & 101 \\
Spring 2008 & Day & $32 \pm 33$ & 24 & $106 \pm 65$ & 86 & $138 \pm 81$ & 112 \\
& Night & $6 \pm 7$ & 3 & $92 \pm 42$ & 86 & $98 \pm 42$ & 94 \\
& ALL & $15 \pm 20$ & 6 & $76 \pm 51$ & 62 & $91 \pm 54$ & 75 \\
& Day & $23 \pm 22$ & 19 & $75 \pm 45$ & 65 & $98 \pm 50$ & 85 \\
& Night & $6 \pm 12$ & 3 & $75 \pm 57$ & 58 & $81 \pm 60$ & 63 \\
& ALL & $17 \pm 34$ & 4 & $156 \pm 541$ & 100 & $175 \pm 548$ & 114 \\
& Day & $21 \pm 32$ & 12 & $121 \pm 90$ & 98 & $145 \pm 114$ & 115 \\
& Night & $11 \pm 33$ & 3 & $132 \pm 112$ & 104 & $145 \pm 129$ & 112 \\
\hline
\end{tabular}

\subsection{Backward trajectories}

We calculated 10-day backtrajectories initialized at three separate hours at three horizontal points surrounding $\mathrm{MBO}$ during specific $\mathrm{NO}_{\mathrm{x}}$ events using the Hybrid SingleParticle Lagrangian Integrated Trajectory (HYSPLIT-4) model (Draxler and Rolph, 2003; http://www.ready.noaa. gov/ready/open/hysplit4.html). These trajectories were calculated using global meteorological data from both the GDAS (Global Data Assimilation System) and NCEP (National Center for Environmental Prediction) Reanalysis archives. The GDAS data have a temporal resolution of $3 \mathrm{~h}$ and a spatial resolution of $1^{\circ} \times 1^{\circ}$ (latitude $\times$ longitude) with a vertical resolution of 23 pressure surfaces between 1000 and $20 \mathrm{hPa}$. The NCEP Reanalysis data have a temporal resolution of $6 \mathrm{~h}$, a spatial resolution of $2.5^{\circ} \times 2.5^{\circ}$, and a vertical resolution of 17 pressure surfaces between 1000 and $10 \mathrm{hPa}$. A third set of backward HYSPLIT trajectories were run for 5 days using meteorological data from the EDAS (Eta Data Assimilation System) archive for events which appeared to have some degree of North American continental or marine influence. The EDAS data cover the continental USA extending offshore several hundred $\mathrm{km}$. The data archive has a temporal resolution of $3 \mathrm{~h}$, a horizontal resolution of $40 \mathrm{~km}^{2}$ (latitude $\times$ longitude) and a vertical resolution of 26 pressure surfaces between 1000 and $50 \mathrm{hPa}$.

Trajectories from all three archives were run at three heights (with $\Delta z=200 \mathrm{~m}$ ) surrounding the summit of MBO starting at $1500 \mathrm{~m}$ above model ground level since the model defines the terrain for the grid box surrounding MBO signif- icantly below the actual altitude of MBO (Weiss-Penzias et al., 2006; Fischer et al., 2010). Using both the GDAS and NCEP meteorological inputs at the three initialization times, three initialization altitudes and three initialization coordinates yields 54 trajectories for each event. Error in HYSPLIT trajectory calculations normal to the direction of flow is 10$30 \%$ of the distance traveled after $24 \mathrm{~h}$ (Draxler and Hess, 1998).

\section{Results and discussion}

\subsection{Basic $\mathrm{NO}_{\mathrm{x}}$ statistics}

Table 1 presents $\mathrm{NO}, \mathrm{NO}_{2}$ and $\mathrm{NO}_{\mathrm{x}}$ data for all five measurement campaigns for which we collected $\mathrm{NO}$ and $\mathrm{NO}_{2}$ data. Note that $\mathrm{NO}_{2}$ measurements did not begin until spring 2007. The first result stemming from Table 1 is the interannual variability. Mean $\mathrm{NO}_{\mathrm{x}}$ mixing ratios during spring 2007 and 2008 were almost identical $119 \pm 65$ and $117 \pm 65$, respectively. However, spring 2009 mean $\mathrm{NO}_{\mathrm{x}}$ concentrations $(91 \pm 54$ pptv) were significantly lower $(p<0.01)$ than both spring 2007 and spring 2008. This decline is seen in both the nighttime (FT) and daytime (BL-influenced) datasets, as well as when all the data are analyzed. We discuss possible reasons for this decline in Sect. 3.4.

The distribution of all the median hourly $\mathrm{NO}_{\mathrm{x}}$ data for the one autumn (28 August-9 October2008) and three spring (15 April-20 May) campaigns is presented in Fig. 2. A slightly non-normal distribution of the data is evident in all spring seasons, whereas the autumn data show a long tail skewed 


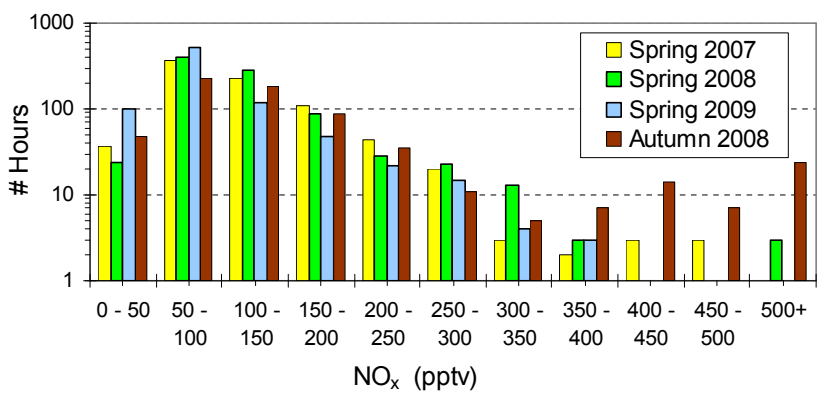

Fig. 2. Distribution of hourly median $\mathrm{NO}_{\mathrm{x}}$ datapoints for the four seasons of interest. Notice the different distribution for autumn 2008 where the data is skewed towards much larger $\mathrm{NO}_{\mathrm{x}}$ values. Also note the $y$-axis is logarithmic.

towards higher $\mathrm{NO}_{\mathrm{x}}$ concentrations. During the autumn 2008 campaign, mean $\mathrm{NO}_{\mathrm{x}}$ was $175 \pm 548 \mathrm{pptv}$. As Table 1 illustrates, mean $\mathrm{NO}_{\mathrm{x}}$ mixing ratios for spring and autumn differ by $\sim 55-85$ pptv $(\sim 50-90 \%)$, but the median mixing ratios do not show such a strong difference. The highly non-normal distribution of the autumn data (skewness coefficient of 19.1 vs. 2.5, 2.8 and 2.4 in spring 2007, 2008 and 2009, respectively) resulted from a few periods of very high $\mathrm{NO}_{\mathrm{x}}$ concentrations. Using MODIS Rapid Response (Aqua and Terra, http://firefly.geog.umd.edu/firemap/) to identify fires in the Pacific Northwest, we find that during autumn our site can be heavily influenced by wildfires in western North America. This is in contrast to springtime, when the smaller positive (i.e., right) tail of the $\mathrm{NO}_{\mathrm{x}}$ distribution is driven largely by ALRT events (see Sects. 3.4 and 3.5). Summer/autumn 2008 was a particularly strong wildfire year in the Pacific Northwest (McKendry et al., 2010), so we cannot definitively conclude that the spring-autumn comparisons presented here are broadly representative.

Diurnal cycles for the four campaigns for which we have $\mathrm{NO}_{\mathrm{x}}$ data are shown in Fig. 3. As expected for a site like $\mathrm{MBO}$ that is far removed from any direct $\mathrm{NO}_{\mathrm{x}}$ emissions, the diurnal cycles for NO (Fig. 3a) show a peak during mid-day (when solar radiation is at its maximum, thereby maximizing the photolysis of $\mathrm{NO}_{2}$ to $\mathrm{NO}$ ) and an overnight minimum of $\sim 0$ pptv (slight deviations from 0 pptv overnight in Fig. 3a represent the NO artifact). Daytime median NO mixing ratios peak between 20-35 pptv with lower values during autumn. The $\mathrm{NO} / \mathrm{NO}_{2}$ ratio in spring is higher, compared to autumm. This reflects the fact that: (1) the dates of the spring campaign (15 April-20 May) lie closer to the summer solstice (as Brasseur et al. (1999) show, photolysis of $\mathrm{NO}_{2}$ at the altitude of Mt. Bachelor can differ by $25-50 \%$ as the solar zenith angle changes from $60^{\circ}$ to $0^{\circ}$ ), and (2) the mountain is almost fully snow-covered during spring. Honrath et al. (2000) found that irradiated snowpack at mid-latitudes can enhance $\mathrm{NO}_{2}$ concentrations by up to 300 pptv. Both factors result in enhanced $J_{\mathrm{NO}_{2}}$ (photolysis rate of $\mathrm{NO}_{2}$ ) values.
The $\mathrm{NO}_{2}$ diurnal cycle (Fig. 3b) exhibits a daytime minimum (when photolysis to NO is at a maximum) and a peak shortly after sunset. This is likely due to two factors: (1) as the sun sets, $\mathrm{NO}$ is quickly oxidized to $\mathrm{NO}_{2}$, and (2) the BL influence maximizes around this time as the surface has heated up, allowing upslope flows to maximize.

As discussed earlier, since most $\mathrm{NO}_{\mathrm{x}}$ emissions are anthropogenic and its lifetime is relatively short (Seinfeld and Pandis, 1998), we expect a strong vertical gradient in $\mathrm{NO}_{\mathrm{x}}$, resulting in much greater $\mathrm{NO}_{\mathrm{x}}$ concentrations in the $\mathrm{BL}$ than in the FT. The $\mathrm{NO}_{\mathrm{x}}$ diurnal cycles (Fig. 3c) mimic characteristics found in the $\mathrm{NO}_{2}$ diurnal cycle, since $\mathrm{NO}_{2}$ concentrations are almost always at least a factor of two greater than $\mathrm{NO}$ concentrations. $\mathrm{NO}_{\mathrm{x}}$ mixing ratios are fairly consistent from around 00:00 PDT through mid-afternoon, peaking within a few hours after sunset as a result of the diurnal pattern in upslope-downslope flows. The median $\mathrm{NO}_{\mathrm{x}}$ diurnal cycle during the autumn (Fig. 3c) campaign was far more muted, however. In contrast, the mean $\mathrm{NO}_{\mathrm{x}}$ diurnal cycle during autumn (Fig. 3d) is substantially greater ( $\sim 40 \mathrm{pptv})$ throughout the entire day than the mean $\mathrm{NO}_{\mathrm{x}}$ diurnal cycles during spring. These results highlight the influence of a few very high $\mathrm{NO}_{\mathrm{x}}$ periods (from regional wildfires) on the overall seasonal $\mathrm{NO}_{\mathrm{x}}$ statistics during autumn 2008.

\subsection{Chairlift soundings}

On 8 days during the spring 2008 campaign we deployed the HOBO instrument to collect "chairlift soundings". From the raw $T$ and RH data, we calculated potential temperature $(\theta)$ and specific humidity $(q)$. Days in which there was either precipitation and/or the mountain was in-cloud for all or part of the time produced data that was not useful in providing an estimation of the onset of a BL-influence at the summit. We obtained 5 days of cloud-free data for spring 2008. Data from one such day (1 May 2008) is shown in Fig. 4. The axes in Fig. $4 \mathrm{a}$ and $\mathrm{b}$ are inverted so the top of the plot represents the top of the mountain. These plots show 26 round-trip ascents and descents of the chairlift. The increases in $T$ (Fig. 4a) and $q$ (Fig. 4b) observed at the summit of the mountain (i.e., at the bottom part of the magenta and orange lines, respectively) coincide with a substantial $(\sim 50 \%)$ increase in $\mathrm{NO}_{\mathrm{x}}$. This simultaneous increase in meteorological and chemical parameters typical of BL-influenced air indicates that some sort of airmass transition is occurring at the time highlighted by the yellow box in Fig. 4 .

Berg and Stull (2004) present "mixing diagrams" ( $q$ vs. $\theta)$ from the Boundary Layer Experiment in 1996, which took place over the Southern Great Plains region of the USA. Such plots are useful in identifying BL vs. FT air since the BL is typically well-mixed and so these parameters are constant with height. In contrast, FT air can be seen when both $q$ and $\theta$ change with height. It follows, then, that a change in airmass type (i.e., a BL-influence) could be detected by a change in the slope of $q$ vs. $\theta$ as it approaches zero. We 

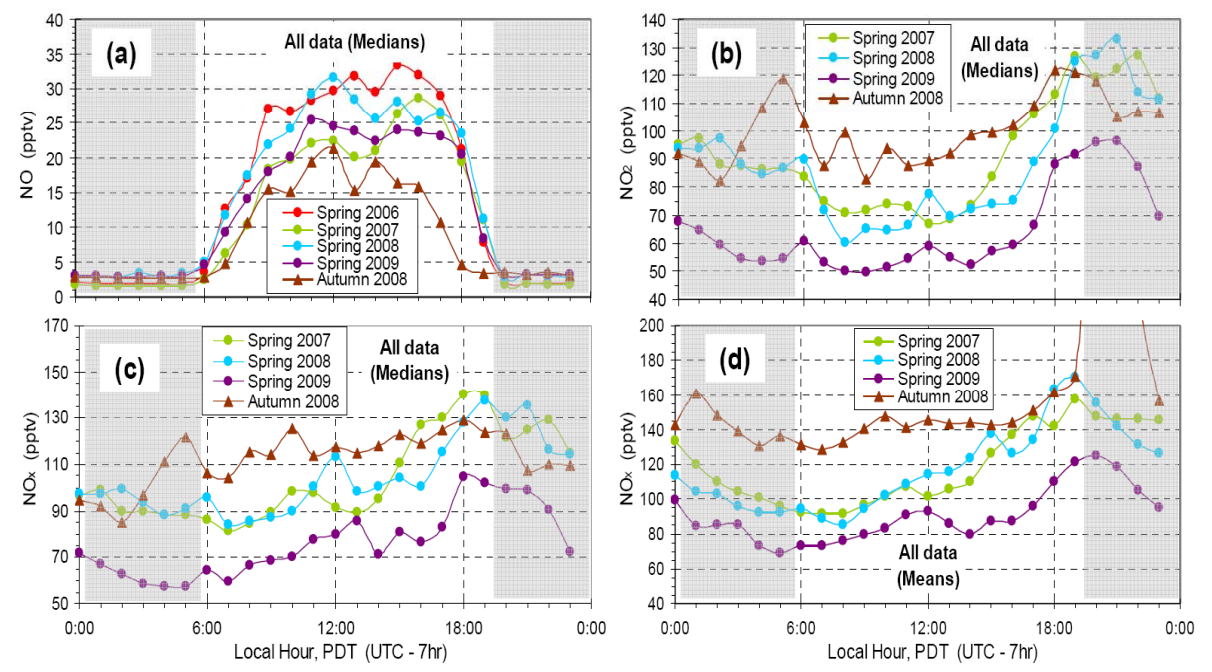

Fig. 3. Median diurnal cycles for (a) $\mathrm{NO}$, (b) $\mathrm{NO}_{2}$ and (c) $\mathrm{NO}_{\mathrm{x}}$ for the four seasons presented in this paper. The mean diurnal cycle in $\mathrm{NO}_{\mathrm{x}}$ is shown in (d). For clarity, we have truncated the y-axis at 200 pptv, but the 20:00-22:00 PDT mean $\mathrm{NO}_{\mathrm{x}}$ values are 337, 596 and 229 pptv, respectively. Gray shading indicates time between local sunset and local sunrise.

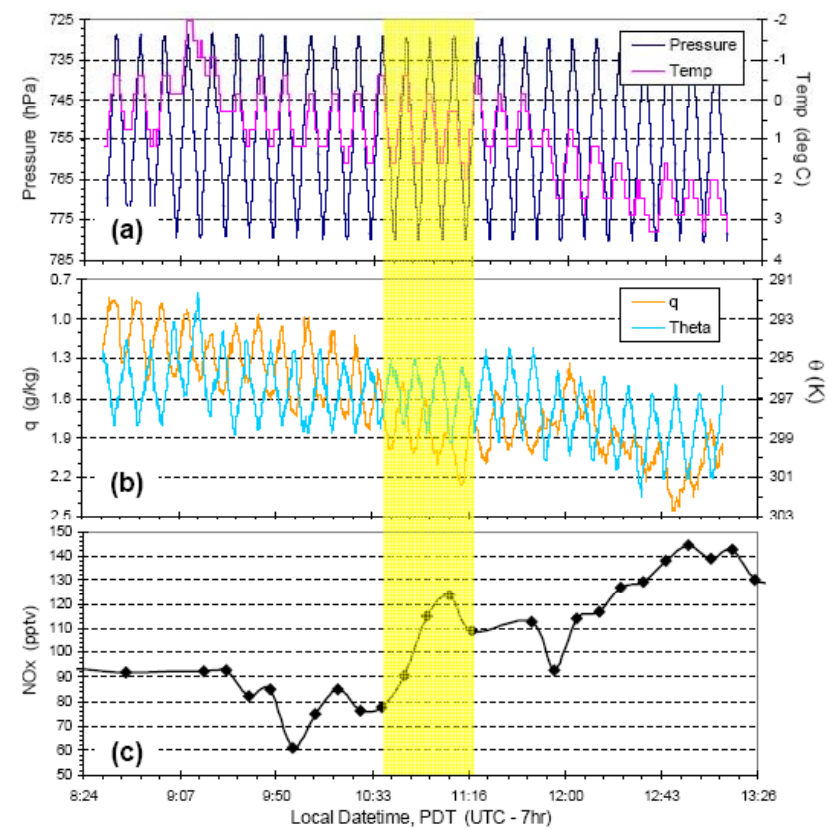

Fig. 4. Chairlift soundings of (a) ambient pressure and temperature and (b) specific humidity, $q$, and potential temperature, $\theta$, along with (c) 10-min $\mathrm{NO}_{\mathrm{x}}$ data for 1 May 2008. Each "cycle" in (a) and (b) represents one full ascent and descent of the chairlift. Note the axes in (a) and (b) are inverted so the top of the plots represent the top of the mountain. The yellow box highlights the time when a transition to a regime in which the summit is beginning to be influenced by the BL is believed to occur.

recognize that this region of the USA is far different from MBO (plains vs. isolated mountain); however, similar plots reveal useful information for MBO. An example from 1 May
2008 is shown in Fig. 5a. Each line in this plot is the average of 3 ascents, with all times stated as PDT (representing the midpoint of the 3 ascents). As the day progresses (gray arrow in Fig. 5a), both $q$ and $\theta$ increase as the air becomes more moist and warmer. Of significance is the change in the slope, particularly at the summit (denoted with cool colors) as the morning progresses. When we plot $d q / d \theta$ against time for the top $\sim 30 \mathrm{hPa}$ (Fig. 5b), the time when this value approaches zero is a good first estimate for when the onset of a BL influence at the summit begins (Berg and Stull, 2004).

We then use this information, along with shifts revealed in the $q, \theta$ and $T$ plots (yellow box in Fig. $4 \mathrm{a}, \mathrm{b}$ ), and the highresolution $\mathrm{NO}_{\mathrm{x}}$ data (Fig. 4c) to pinpoint when this BL influence begins. These results are summarized in Table 2 for the 5 days we have clear-sky HOBO data. While the sample size is relatively small ( $n=5$ days), there is little variability in the timing, so we can use the average of these times to estimate a seasonal-mean time-of-day in which the BL influence begins atop Mt. Bachelor. This time is $\sim 10: 15$ PDT, which is $\sim 5 \mathrm{~h}$ after local sunrise. To allow a few hours of transition we identify BL-influenced data as being from $5 \mathrm{~h}$ after sunrise through $1 \mathrm{~h}$ after sunset. Similarly, we label FT data as being from $5 \mathrm{~h}$ after sunset through $1 \mathrm{~h}$ after sunrise for clear-sky days. We segregated the $\mathrm{NO}_{\mathrm{x}}$ data using this criterion with results presented in Table 1. This time-of-day segregation technique was better than a segregation based on specific humidity at separating the high- $\mathrm{NO}_{\mathrm{x}}$ concentrations attributable to a $\mathrm{BL}$ influence from the lower $\mathrm{FT} \mathrm{NO}_{\mathrm{x}}$ mixing ratios during spring. For example, using the 20th (vs. 80th) percentile of specific humidity to identify FT (vs. BL-influenced) air, $\mathrm{NO}_{\mathrm{x}}$ for spring 2007 was $111 \pm 73$ pptv (vs. $125 \pm 52 \mathrm{pptv}$ ) - a difference of $14 \mathrm{pptv}$ in the means. Similar values for the time-of-day segregation of FT (vs. BL-influenced) air for 

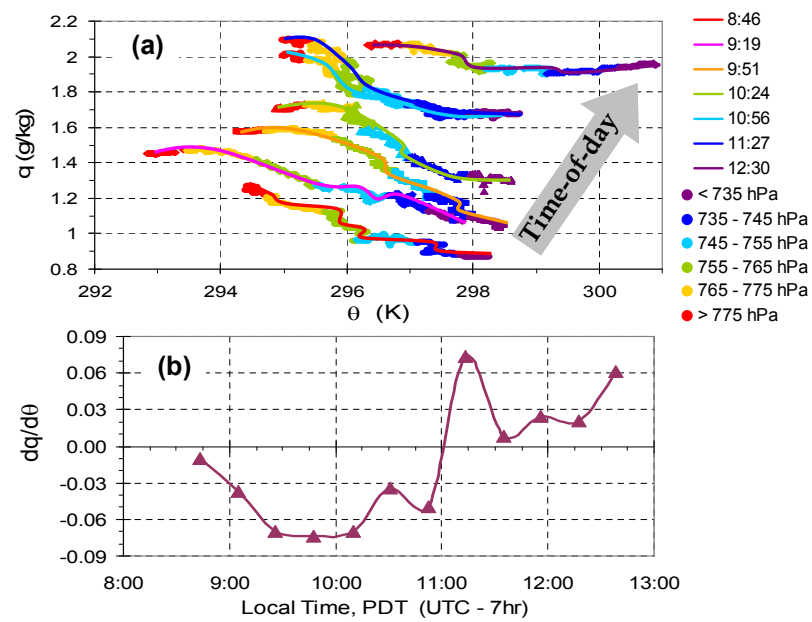

Fig. 5. (a) An example "mixing diagram" (after the work of Berg and Stull, 2004) for 1 May 2008. The individual points along each line are averaged from 3 ascents presented in Fig. 4; the line atop the points represents a fit to the averaged points. All times are local (PDT $=\mathrm{UTC}-$ 07:00 h) and are the midpoints of the 3 ascents. Note the change in the shape of the curve (particularly at the summit, denoted here in cool colors) as the morning progresses. (b) An example $d q / d \theta$ vs. time-of-day plot for 1 May 2008. Points represent the average of 2 ascents presented in Fig. 4 to allow for greater resolution than panel (a).

spring 2007 were $106 \pm 57$ pptv (vs. $131 \pm 68$ pptv) - a difference of $25 \mathrm{pptv}$ in the means. Segregating the $\mathrm{NO}_{\mathrm{x}}$ timeseries by percentile of water vapor yielded a smaller difference (14 pptv) between the "wet" and "dry" datasets than by segregating the timeseries by time-of-day, which yielded a "day (BL-influenced)" vs. "night (FT)" difference in $\mathrm{NO}_{\mathrm{x}}$ of 25 pptv. Similar differences are also seen in comparing the spring 2008 and spring 2009 data. In contrast, however, the specific humidity segregation is a better segregating criterion than time-of-day for the autumn $2008 \mathrm{NO}_{\mathrm{x}}$ data. For consistency, though, we only present the day vs. night comparisons in Table 1 for autumn 2008. In summary, these results show that the chairlift soundings provide a time-of-day segregating criterion that works well for the springtime $\mathrm{NO}_{\mathrm{x}}$ data. Using this segregation method, Table 1 illustrates that the spring 2007-2008 vs. 2009 differences in $\mathrm{NO}_{\mathrm{x}}$ are present in all airmasses.

\subsection{Comparison to other $\mathrm{NO}_{\mathrm{x}}$ observations}

The $\mathrm{NO}_{\mathrm{x}}$ observations presented here are the first such multiseason, multi-year observations made at a remote site ideally situated to detect pollution inflow to North America. A comparison of our data with $\mathrm{NO}_{\mathrm{x}}$ data from aircraft observations in this region and from other mid-latitude mountaintop sites gives us a better understanding of its global distribution. Figure 6 highlights regions where reactive nitrogen was previously measured aboard aircraft in the Asia-Pacific-North
Table 2. Estimation of the timing of the onset of a BL influence at the summit of $\mathrm{MBO}$ using the chairlift sounding and $\mathrm{NO}_{\mathrm{X}}$ data. $\Delta \mathrm{NO}_{\mathrm{x}}$ values indicate the difference between the $3 \mathrm{~h}$ average $\mathrm{NO}_{\mathrm{x}}$ before and after the time listed in the middle column.

\begin{tabular}{lcc}
\hline Date & $\begin{array}{c}\text { Time of onset of BL } \\
\text { influence (Local ime) }\end{array}$ & $\Delta \mathrm{NO}_{\mathrm{x}}, \mathrm{pptv}(\%)$ \\
\hline 11.04 .2008 & $10: 45-11: 15$ & $74(118 \%)$ \\
25.04 .2008 & $09: 00-09: 30$ & $88(99 \%)$ \\
01.05 .2008 & $10: 45-11: 15$ & $36(45 \%)$ \\
07.05 .2008 & $09: 00-09: 30$ & $30(30 \%)$ \\
08.05 .2008 & $10: 15-10: 45$ & $45(72 \%)$ \\
Mean & $\mathbf{1 0 : 0 0 - 1 0 : 3 0}$ & $\mathbf{5 5}(\mathbf{7 3 \%})$ \\
\hline
\end{tabular}

America area. Stars in Fig. 6 depict mountaintop sites for which reactive nitrogen data have been published.

\subsubsection{Comparisons to aircraft observations}

Table 3a summarizes reactive nitrogen measurements from the various aircraft campaigns. As mentioned earlier, the main loss $(60-70 \%)$ of $\mathrm{NO}_{\mathrm{y}}$ during transport from Chinese sources occurs when the airmass is exported out of the Chinese BL and into the Western Pacific atmosphere (Koike et al., 2003). The $\mathrm{NO}_{\mathrm{y}} / \mathrm{CO}$ ratios were similar in each Asian pollution plume identified during the ITCT-2K2 campaign and significantly lower than those derived from estimated Asian emission ratios, indicating substantial removal of soluble $\mathrm{NO}_{\mathrm{y}}$ species during transport from the $\mathrm{BL}$ to the FT (Nowak et al., 2004). By comparison, there is very little loss during trans-Pacific transport in the FT. The partitioning of $\mathrm{NO}_{\mathrm{y}}$ may very well shift during this FT transit, but the total $\mathrm{NO}_{\mathrm{y}}$ does not change substantially once it has been lofted into the FT. Nowak et al. (2004) showed that $\mathrm{NO}_{\mathrm{y}}$ was primarily in the form of PAN in plumes that were transported in cold high-latitude and high-altitude regions, whereas in plumes transported in warmer, lower latitude and altitude regions, $\mathrm{NO}_{\mathrm{y}}$ was mainly $\mathrm{HNO}_{3}$. Table $3 \mathrm{a}$ also reveals that not many measurements of $\mathrm{NO}_{\mathrm{x}}$ have been published in this Asia-Pacific-North America region. Most measurements indicate $\mathrm{NO}_{\mathrm{x}}$ mixing ratios range from $30-60 \mathrm{pptv}$. Tang et al. (2004) reported mean observed $\mathrm{NO}_{\mathrm{x}}$ mixing ratios in the FT ( $>3 \mathrm{~km})$ of 74 pptv during ITCT-2K2 over the eastern Pacific. These values are quite comparable to the mean springtime FT $\mathrm{NO}_{\mathrm{x}}$ levels observed at MBO of 95 pptv. The differences illustrated in Table 3a are manifested more in the $\mathrm{NO}_{\mathrm{y}}$ data than in the $\mathrm{NO}_{\mathrm{x}}$ data, which is likely due to the different partitioning of $\mathrm{NO}_{\mathrm{y}}$ discussed earlier (though, again, this could be due to the few published $\mathrm{NO}_{\mathrm{x}}$ data from these campaigns). 


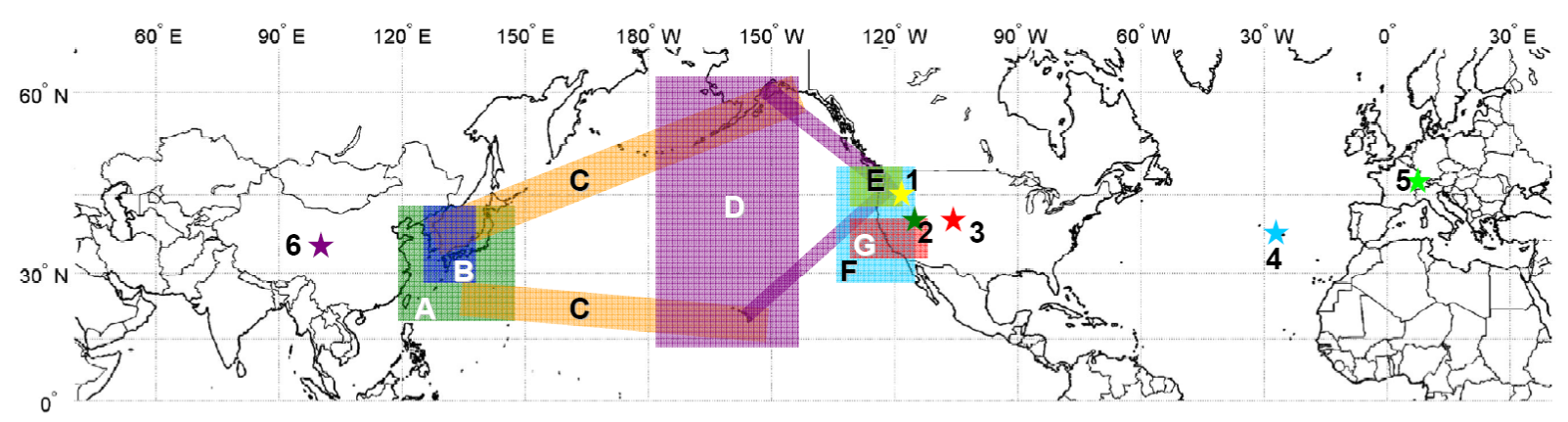

Fig. 6. Geographic location of aircraft campaigns (depicted by shaded boxes and letters) studying pollution outflow from Asia, its transformation over the Pacific and its influence on inflow to North America. See Table 3a for details. Geographic location of Northern Hemisphere mid-latitude mountain sites (depicted by stars and numbers) with $\mathrm{NO}$ and/or $\mathrm{NO}_{\mathrm{x}}$ observations. See Table $3 \mathrm{~b}$ for details.

Table 3a. Details on aircraft campaigns studying Asian pollution transport depicted in Fig. 6 along with $\mathrm{NO}, \mathrm{NO}_{2}, \mathrm{NO}_{\mathrm{x}}$ and $\mathrm{NO}_{\mathrm{y}}$ data where available. Values denoted with an asterisk $(*)$ are means; all other values are medians.

\begin{tabular}{|c|c|c|c|c|c|c|c|c|c|}
\hline Region & Legend & Campaign & Date & Altitude (km) & $\begin{array}{l}\text { NO } \\
\text { (pptv) }\end{array}$ & $\begin{array}{l}\mathrm{NO}_{2} \\
\text { (pptv) }\end{array}$ & $\begin{array}{l}\mathrm{NO}_{\mathrm{x}} \\
\text { (pptv) }\end{array}$ & $\begin{array}{l}\mathrm{NO}_{\mathrm{y}} \\
\text { (pptv) }\end{array}$ & Reference \\
\hline \multirow{6}{*}{ Asian Outflow } & \multirow{5}{*}{ A } & \multirow{5}{*}{ TRACE-P } & \multirow{5}{*}{ Spring 2001} & $0-2$ & - & $70 *$ & - & - & \multirow[b]{2}{*}{ Nakamura et al., 2003} \\
\hline & & & & $2-8$ & - & $30 *$ & - & - & \\
\hline & & & & 4 & - & - & - & $900 *$ & Koike et al., 2003 \\
\hline & & & & $2-7$ & - & - & $30^{*}$ & $377^{*}$ & Talbot et al., 2003 \\
\hline & & & & $\sim 3$ & - & - & 60 & 670 & Miyazaki et al., 2003 \\
\hline & B & PEACE-A & Winter 2002 & $2-3$ & - & - & $250^{*}$ & $1100^{*}$ & Takegawa et al., 2004 \\
\hline \multirow{7}{*}{ Remote Pacific } & \multirow{3}{*}{$\mathrm{C}$} & \multirow{3}{*}{ PEM-West-A (more maritime) } & \multirow{3}{*}{ Autumn 1991} & $2-4$ (continental) & - & - & $51^{*}$ & $395^{*}$ & \multirow{3}{*}{$\begin{array}{l}\text { Koike et al., } 1996 \\
\text { Singh et al., } 1998\end{array}$} \\
\hline & & & & 2-4 (maritime) & - & - & $33^{*}$ & $227 *$ & \\
\hline & & & & "lower troposphere", $40^{\circ} \mathrm{N}$ & - & - & $100 *$ & $900 *$ & \\
\hline & \multirow{2}{*}{$\mathrm{C}$} & \multirow{2}{*}{$\begin{array}{l}\text { PEM-West-B } \\
\text { (more continental) }\end{array}$} & \multirow{2}{*}{ Spring 1994} & "lower troposphere" & 19 & - & 60 & 540 & \multirow{2}{*}{$\begin{array}{l}\text { Kondo et al., } 1997 \\
\text { Talbot et al., } 2003\end{array}$} \\
\hline & & & & $2-7$ & $16^{*}$ & - & - & $328^{*}$ & \\
\hline & \multirow{2}{*}{$\mathrm{D}$} & \multirow{2}{*}{ INTEX-B } & \multirow{2}{*}{ Spring 2006} & 2-4 (North of $\left.45^{\circ} \mathrm{N}\right)$ & - & - & $41^{*}$ & $414^{*}$ & \multirow{2}{*}{ Bertram, 2006} \\
\hline & & & & 2-4 (South of $\left.45^{\circ} \mathrm{N}\right)$ & - & - & $45^{*}$ & $319^{*}$ & \\
\hline \multirow{6}{*}{$\begin{array}{l}\text { North American } \\
\text { Inflow }\end{array}$} & \multirow{2}{*}{$\mathrm{F}$} & \multirow{2}{*}{ ITCT-2K2 } & \multirow{2}{*}{ Spring 2002} & $2-3$ & $20 *$ & - & - & - & \multirow{3}{*}{$\begin{array}{l}\text { Hudman et al., } 2004 \\
\text { Tang et al., } 2004 \\
\text { Kotchenruther et al., 2001b }\end{array}$} \\
\hline & & & & $>3$ & $19 *$ & $55^{*}$ & $74^{*}$ & $420 *$ & \\
\hline & $\mathrm{E}$ & PHOBEA & 1997-2002 & $2-4$ & $12.5^{*}$ & - & - & - & \\
\hline & \multirow{2}{*}{$\mathrm{G}$} & \multirow{2}{*}{ CITE-1 } & Autumn 1984 & $2.5-3$ & $15^{*}$ & - & - & - & Davis et al., 1987 \\
\hline & & & Spring 1984 & $2-4$ & $6^{*}$ & - & - & - & Chameides et al., 1989 \\
\hline & $\mathrm{G}$ & GTE & Autumn 1983 & $2-3$ & $10^{*}$ & - & - & - & Ridley et al., 1987 \\
\hline
\end{tabular}

\subsubsection{Comparisons to ground-site observations}

Table $3 \mathrm{~b}$ presents $\mathrm{NO}_{\mathrm{x}}$ observations for other mid-latitude mountaintop sites around the Northern Hemisphere. This table reveals quite a bit about the unique geography around each site. Big Hill, for instance, is in the western Sierra Nevada Range of California (USA). It experiences diurnal upslope/downslope flows that bring pollution from the Central Valley to the site (Murphy et al., 2006). Even during night, however, $\mathrm{NO}_{2}$ mixing ratios are almost 200 pptv, far above what we observe at MBO. This is likely due to the fact that: (a) these are summer values (when local wildfires likely increase regional $\mathrm{NO}_{\mathrm{x}}$ concentrations), (b) the altitude is $1.86 \mathrm{~km}$ a.s.l., far lower than at $\mathrm{MBO}$ and therefore more likely to have a BL influence and (c) there is a complex recirculation of anthropogenic pollution from the Californian
Central Valley influencing the site. The $\mathrm{NO}_{\mathrm{x}}$ mixing ratios observed at Niwot Ridge, Colorado (USA) in the Rocky Mountains are substantially greater than those observed at other mountaintop sites. This is largely because of the continental location of this site, coupled with the fact that it frequently samples air from the Denver metropolitan area (Fahey et al., 1986). The Pico Mountain site on the Azores, located in the central North Atlantic, observes the lowest $\mathrm{NO}_{\mathrm{x}}$ mixing ratios of any site in the list (including MBO) due to its complete isolation from any nearby continental influences. Its location makes it an ideal site to further our understanding of the evolution of North American pollution outflow (Val Martin et al., 2008a, b). The Jungfraujoch site in the Swiss Alps detects $\mathrm{NO}_{\mathrm{x}}$ mixing ratios that are most akin to those observed at MBO. As described in Sect. 2.3.1., a great deal of research has been done to isolate "background" or FT air 
Table 3b. Details for the mountain sites depicted in Fig. 6 with corresponding $\mathrm{NO}, \mathrm{NO}_{2}\left(\mathrm{NO}_{\mathrm{x}}\right)$ and $\mathrm{NO}_{\mathrm{y}}$ data where available. Values with an asterisk (*) are means; all other values are medians.

\begin{tabular}{|c|c|c|c|c|c|c|c|c|c|}
\hline Site & Legend & Coordinates & $\begin{array}{l}\text { Elevation } \\
\text { (km a.s.l.) }\end{array}$ & Conditions & $\begin{array}{l}\text { NO } \\
\text { (pptv) }\end{array}$ & $\begin{array}{l}\mathrm{NO}_{2} \\
\text { (pptv) }\end{array}$ & $\begin{array}{l}\mathrm{NO}_{\mathrm{x}} \\
(\mathrm{pptv})\end{array}$ & $\begin{array}{l}\mathrm{NO}_{\mathrm{y}} \\
\text { (pptv) }\end{array}$ & Reference \\
\hline \multirow{3}{*}{ Mt. Bachelor } & \multirow{3}{*}{1} & \multirow{3}{*}{$44.0^{\circ} \mathrm{N}, 121.7^{\circ} \mathrm{W}$} & \multirow{3}{*}{2.73} & 2007-09 Spring All & 7 & 78 & 92 & - & \multirow{3}{*}{ this work } \\
\hline & & & & 2007-09 Spring_Day / BL & 21 & 81 & 103 & - & \\
\hline & & & & 2007-09 Spring_Night / FT & 3 & 77 & 82 & - & \\
\hline \multirow[b]{2}{*}{ Big Hill } & \multirow[b]{2}{*}{2} & \multirow{2}{*}{$38.84^{\circ} \mathrm{N}, 120.41^{\circ} \mathrm{W}$} & \multirow[b]{2}{*}{1.86} & 2003 Summer Day & - & 319 & - & 1864 & \multirow[b]{2}{*}{ Murphy et al., 2006} \\
\hline & & & & 2003 Summer Night & - & 198 & - & 1321 & \\
\hline \multirow{3}{*}{ Niwot Ridge } & \multirow{3}{*}{3} & \multirow{3}{*}{$40.2^{\circ} \mathrm{N}, 105.32^{\circ} \mathrm{W}$} & \multirow{3}{*}{3.05} & 1984 Summer Night & - & - & $550^{*}$ & $1050 *$ & \multirow{3}{*}{ Fahey et al., 1986} \\
\hline & & & & 1984 Autumn Day & - & - & $610^{*}$ & $1000 *$ & \\
\hline & & & & 1984 Autumn Night & - & - & $250 *$ & $780^{*}$ & \\
\hline \multirow{4}{*}{ Pico Mtn } & \multirow{4}{*}{4} & \multirow{4}{*}{$38.47^{\circ} \mathrm{N}, 28.40^{\circ} \mathrm{W}$} & \multirow{4}{*}{2.20} & 2002-05 Spring & - & - & $26 *$ & $180^{*}$ & \multirow{4}{*}{$\begin{array}{l}\text { Val Martin et al., 2008b } \\
\text { Val Martin et al., 2008a }\end{array}$} \\
\hline & & & & 2004 Summer & - & - & 27 & 169 & \\
\hline & & & & 2005 Summer & - & - & 28 & 234 & \\
\hline & & & & 2002-05 Spring Day & 7 & 21 & 26 & 178 & \\
\hline \multirow{12}{*}{ Jungfraujoch } & \multirow{12}{*}{5} & \multirow{12}{*}{$46.55^{\circ} \mathrm{N}, 7.98^{\circ} \mathrm{E}$} & \multirow{12}{*}{3.58} & 1998 Spring All & 15 & 155 & 170 & 957 & \multirow{5}{*}{ Zanis et al., 2000} \\
\hline & & & & 1998 Spring Day & 37 & 168 & 205 & - & \\
\hline & & & & 1998 Spring All FT & 9 & 79 & 88 & 625 & \\
\hline & & & & 1998 Spring Day FT & 22 & 83 & 105 & - & \\
\hline & & & & 1997 Summer All & 12 & 170 & 192 & 913 & \\
\hline & & & & 1997 Summer FT & $<\mathrm{DL}$ & 76 & 77 & 231 & \multirow{2}{*}{ Zellweger et al., 2000} \\
\hline & & & & 1997 Summer BL & 11 & 168 & 188 & 958 & \\
\hline & & & & 1997-99 Spring FT & - & - & 98 & 581 & \multirow{2}{*}{ Zellweger et al., 2003} \\
\hline & & & & 1997-99 Spring FT-BL mix & - & - & 204 & 981 & \\
\hline & & & & 2005 Spring Background & $16^{*}$ & $42 *$ & $52 *$ & $740^{*}$ & \\
\hline & & & & 2005 Summer Background & $15^{*}$ & $50 *$ & $56^{*}$ & $879 *$ & Balzani Lööv et al., 2008 \\
\hline & & & & 2005 Autumn Background & $9^{*}$ & $14 *$ & $14 *$ & $489^{*}$ & \\
\hline \multirow{3}{*}{ Mt. Waliguan } & \multirow{3}{*}{6} & & & 2003 Spring Downslope & $13 *$ & - & - & $3950 *$ & \\
\hline & & $36.28^{\circ} \mathrm{N}, 100.90^{\circ} \mathrm{E}$ & 3.82 & 2003 Spring Upslope & $72 *$ & - & - & $3700 *$ & Wang et al., 2006 \\
\hline & & & & 2003 Summer Upslope & $47 *$ & - & - & $3820 *$ & \\
\hline
\end{tabular}

at this site (Zanis et al., 2000; Zellweger et al., 2000, 2003). Finally, the Mt. Waliguan site in eastern China is the highest above sea level on our list, yet also observes the largest levels of $\mathrm{NO}_{\mathrm{y}}$. However, it is situated on the Tibetan Plateau, so its height above sea level is significantly higher than the surrounding plains. As a result, Wang et al. (2006) attribute the elevated $\mathrm{NO}_{\mathrm{y}}$ mixing ratios to the intense grazing agriculture around the mountain's base. The differences among these sites is not purely due to differing regional geographies, but also regional changes in $\mathrm{NO}_{\mathrm{x}}$ emissions from 1984-2009 (when $\mathrm{NO}_{\mathrm{x}}$ observations listed in Table $3 \mathrm{~b}$ were obtained).

\subsubsection{C-130 aircraft fly-by of Mt. Bachelor during INTEX-B campaign}

During spring 2006, MBO participated in NASA's INTEXB campaign (Singh et al., 2009). On three days, the National Center for Atmospheric Research C-130 aircraft made "fly-by's" of MBO to allow an inter-platform comparison of various measurements. Table 4 summarizes the comparisons of $\mathrm{MBO}$ vs. C-130 $\mathrm{NO}$ and $\mathrm{NO}_{2} / \mathrm{NO}$ ratio (C-130 data provided by $\mathrm{G}$. Chen). Recall, during $2006 \mathrm{NO}_{2}$ data was not available, so we have used the hourly median $\mathrm{NO}_{2}$ data from
MBO for the month and hour during which the C-130 flew by the mountain (e.g., 24 April 2006 at 12:08 PDT was the first fly-by, so the 2007-09 median $\mathrm{NO}_{2}$ mixing ratio for the 12:00 PDT hour during April from MBO is used in the comparison). These comparisons show that there was excellent agreement (no statistically significant differences) in the NO data, from concentrations ranging from 10-40 pptv. We use the $\mathrm{NO}_{2} / \mathrm{NO}$ as opposed to direct $\mathrm{NO}_{2}$ comparisons, since we are capable of making direct comparisons of NO data from the two platforms. Median $\mathrm{NO}_{2} / \mathrm{NO}$ ratios aboard the $\mathrm{C}-130$ during the four fly-bys ranged from 0.9-3.7 (all fly-bys occurred between 10:00-16:00 PDT). Median $\mathrm{NO}_{2} / \mathrm{NO}$ ratios at $\mathrm{MBO}$ for the hours of the fly-bys during the month of relevance ranged from 2.3-3.2, so the ranges are comparable. We recognize, as Chameides et al. (1990) stated, that large, random variations are associated with $\mathrm{NO}_{\mathrm{x}}$ measurements in the remote FT, making comparisons of $\mathrm{NO}_{2} / \mathrm{NO}$ from individual time intervals statistically meaningless. However, we took great care to devise a metric from the $\mathrm{MBO} \mathrm{NO}_{\mathrm{x}}$ data that would be representative for comparison with the C-130 aircraft data. In the end, this is the best we can do with the available data. 
Table 4. Comparison of MBO data to data collected aboard the NCAR C-130 aircraft during fly-by's of MBO as part of the INTEX-B campaign in spring 2006. The column denoted with an asterisk (*) indicates that 2007-09 median or mean $\mathrm{NO}_{2}$ (and NO) values for the hour of day and the month in which the fly-by occurred are used since $\mathrm{NO}_{2}$ measurements were not made at MBO until 2007 . C-130 aircraft data provided by Gao Chen (at NASA) and is presented as the median of the $1 \mathrm{~s}$ data within $25 \mathrm{~km}$ of MBO horizontally and within $100 \mathrm{~m}$ of its summit.

\begin{tabular}{|c|c|c|c|c|c|c|}
\hline \multirow{3}{*}{ Date } & \multirow{3}{*}{ Local Time (PDT) } & \multicolumn{2}{|c|}{ NO (pptv) } & \multicolumn{3}{|c|}{$\mathrm{NO}_{2} / \mathrm{NO}$} \\
\hline & & MBO & C-130 & & $\mathrm{BO}^{*}$ & C-130 \\
\hline & & mean $\pm 1 \sigma$ & mean $\pm 1 \sigma$ & median & mean $\pm 1 \sigma$ & mean $\pm 1 \sigma$ \\
\hline $4 / 24 / 2006$ & $12: 08$ & $39 \pm 11$ & $43 \pm 13$ & 2.3 & $3.1 \pm 2.2$ & $1.1 \pm 0.4$ \\
\hline $5 / 3 / 2006$ & $12: 35$ & $23 \pm 7$ & $16 \pm 2$ & 2.9 & $3.7 \pm 3.3$ & $2.6 \pm 0.8$ \\
\hline 5/8/2006 A & 10:05 & $12 \pm 1$ & $10 \pm 1$ & 3.2 & $4.6 \pm 4.4$ & $3.9 \pm 1.4$ \\
\hline $5 / 8 / 2006 \mathrm{~B}$ & $16: 06$ & $18 \pm 2$ & $17 \pm 7$ & 2.8 & $3.7 \pm 3.2$ & $3.0 \pm 0.8$ \\
\hline
\end{tabular}

\subsection{Explaining interannual variability in $\mathrm{NO}_{\mathrm{x}}$ observed at MBO}

As discussed earlier, the majority of global $\mathrm{NO}_{\mathrm{x}}$ emissions are anthropogenic. As a result, interannual variability in $\mathrm{NO}_{\mathrm{x}}$ at a site like MBO that is far removed from sources is likely to be driven by changes in meteorology (Delmas et al., 1997). Figure 7 shows the $600 \mathrm{hPa}$ synoptic climatology in (a) geopotential height, (b) vector winds, and (c) vertical velocity for spring (15 April-20 May) over the AsiaPacific-North America region (from NCEP reanalysis, http: //www.esrl.noaa.gov/psd/data/composites/day/). Figure 7a, b illustrates the strong southwesterly flow (in the western Pacific) followed by intense zonal flow across the Pacific - a situation that facilitates the long-range transport of pollution from Asia to western North America (Liang et al., 2005). Figure $7 \mathrm{c}$ completes the meteorological picture showing subsidence over the western USA that is strongest off the coast of California. Zhang et al. (2008) have shown this to be a region of strong $\mathrm{O}_{3}$ production due to the thermal decomposition of PAN as airmasses subside. These plots of seasonal mean synoptic patterns show that the vast majority of air arriving at $\mathrm{MBO}$ has traveled north of $\sim 35^{\circ} \mathrm{N}$. As a result, synoptic anomalies in this North Pacific region are likely to affect air arriving at MBO.

Springtime anomalies in geopotential heights and vector winds for 2007, 2008 and 2009 are shown in Fig. 8 for the same region presented in Fig. 7. Anomalies in these parameters can change the efficiency of trans-Pacific transport. Two striking features can be seen, as highlighted with white boxes in Fig. 8c, f. First, anomalously high geopotential heights are seen in the FT over the northern Pacific and Alaska. Anomaly plots for air temperature (not shown here) mirror those presented in Fig. 8c, with anomalously high geopotential heights strongly linked to anomalously warm temperatures. For example, in the region where the geopotential height anomaly is greatest in Fig. $8 \mathrm{c}(+90 \mathrm{hPa})$, the accompanying temperature anomaly is $+4^{\circ} \mathrm{C}$. If PAN was a significant contributor to $\mathrm{NO}_{\mathrm{x}}$ observed at $\mathrm{MBO}$ and air arriving

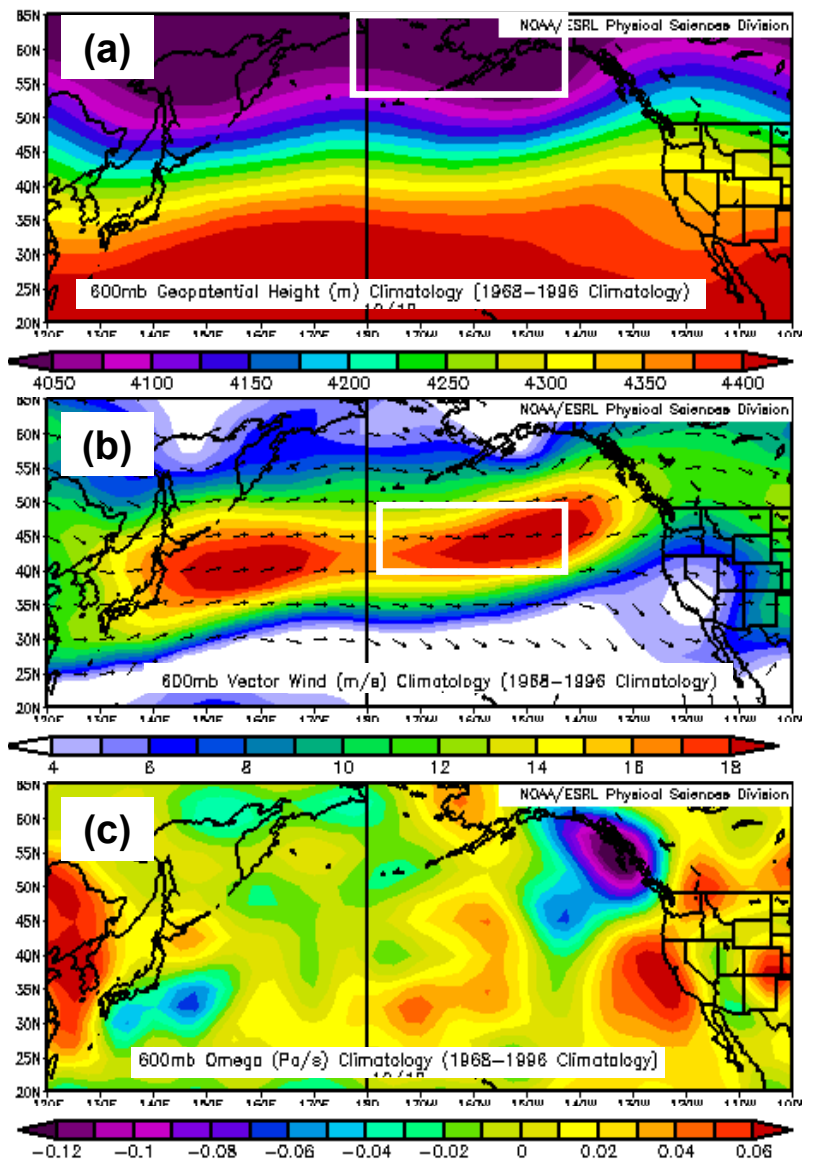

Fig. 7. Climatology of synoptic-scale meteorological parameters during 15 April-20 May from NCEP reanalysis (http://www.esrl. noaa.gov/psd/data/composites/day/) at $600 \mathrm{hPa}$ (i.e., the free troposphere): (a) geopotential height, (b) vector winds, and (c) vertical velocity. The white boxes in (a) and (b) indicate regions where substantial anomalies occurred during spring 2009, as highlighted in Fig. $8 \mathrm{c}$ and $\mathrm{f}$ and discussed in Sect. 3.4. 

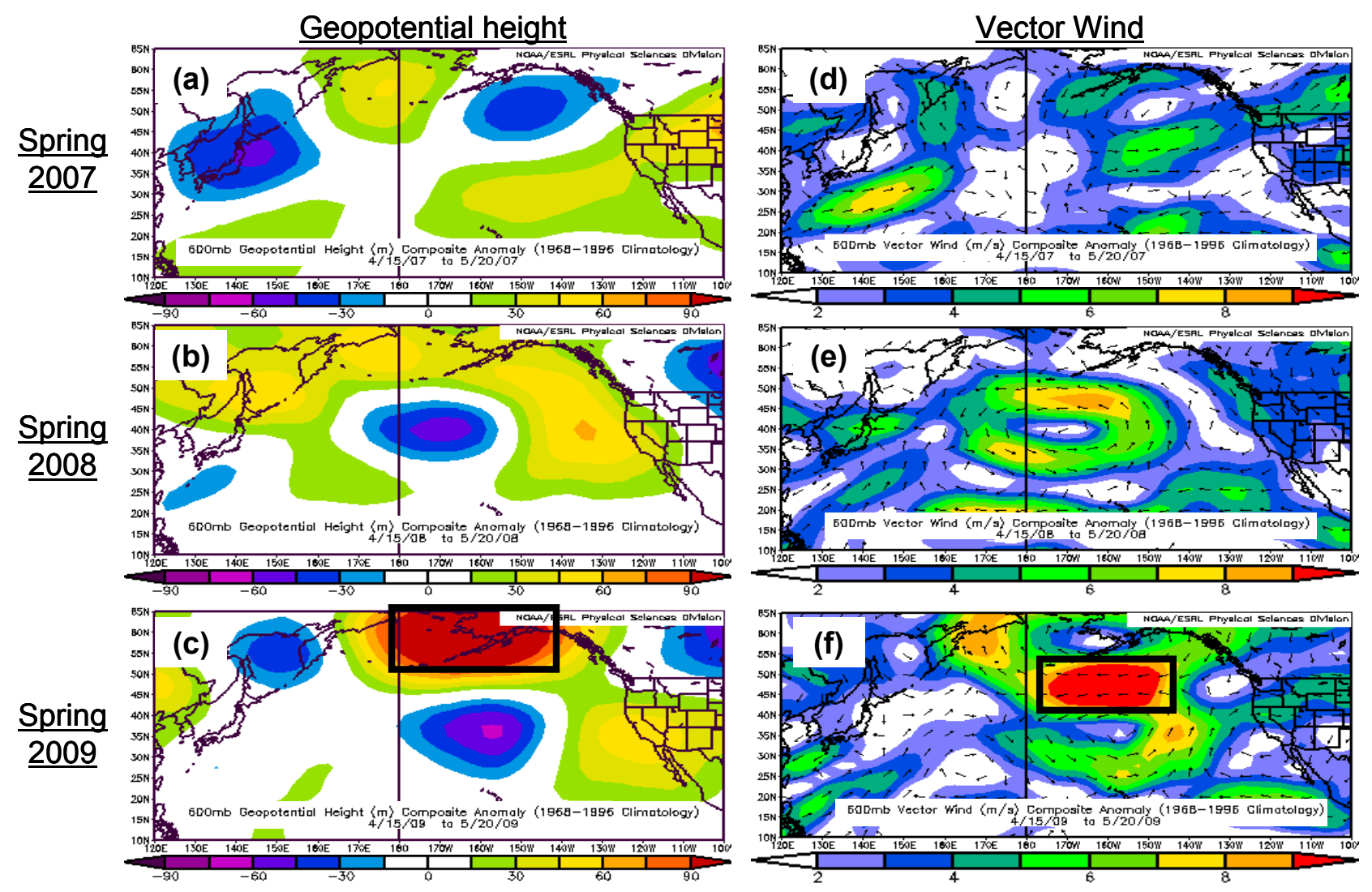

Fig. 8. Springtime FT ( $600 \mathrm{hPa})$ anomalies (from NCEP reanalysis) of (left) geopotential height and (right) vector winds for (top) 2007, (middle) 2008, and (bottom) 2009. The black boxes in (c) and (f) indicate regions where substantial anomalies occurred during spring 2009.

at MBO traveled through this region (as Fischer et al. (2010) have shown it can), then relative to the two previous spring seasons, as PAN was transported through this region of the North Pacific during spring 2009 more $\mathrm{NO}_{\mathrm{x}}$ would be released due to the shorter lifetime of PAN under warmer temperatures. The anomaly of $+4{ }^{\circ} \mathrm{C}$ corresponds to a change in mean temperature in this region at this altitude from a climatological value of $\sim-12^{\circ} \mathrm{C}$ to $-8^{\circ} \mathrm{C}$. This translates to an approximate decrease in the PAN lifetime from $\sim 680$ sunlit hours to $\sim 200$ sunlit hours. As Fischer et al. (2010) show, this change could result in substantial re-partitioning of $\mathrm{NO}_{\mathrm{y}}$ from PAN to $\mathrm{NO}_{\mathrm{x}}$ in the NE Pacific during spring. Transport from this region to $\mathrm{MBO}$ is $\sim 3-5$ days, which is greater than the lifetime of $\mathrm{NO}_{\mathrm{x}}$. Thus, we might expect lower $\mathrm{NO}_{\mathrm{x}}$ at MBO during spring 2009 due to this anomalous synoptic feature.

Another anomaly exists in FT vector winds during spring 2009. Fig. 8f shows mean spring FT winds in the central Pacific during 2009 to be about half of what they were in 2007 or $2008(\sim 9 \mathrm{~m} / \mathrm{s}$ vs. $18 \mathrm{~m} / \mathrm{s})$. This increases the trans-Pacific transit time, allowing further reactivity of any $\mathrm{NO}_{\mathrm{x}}$ present in the central Pacific FT. As discussed previously, $\mathrm{NO}_{\mathrm{x}}$ concentrations are expected to be relatively low in the FT over the central Pacific, but the much weaker winds facilitate en- hanced dispersion of $\mathrm{NO}_{\mathrm{x}}$ and PAN. Consequently, we expect a reduction in the seasonal-mean influence from Asian emissions on western North America. Note this does not imply that fewer ALRT events reached western North America during spring 2009. Rather, our best estimate is that transPacific transport was slower during spring 2009, which resulted in a reduction in $\mathrm{NO}_{\mathrm{x}}$ mixing ratios observed at $\mathrm{MBO}$ when compared to the two previous spring seasons.

To analyze these anomalies in more detail, we explore the interannual variability in the LRT3 index developed by Liang et al. (2005). Briefly, the LRT3 index is based on sea level pressure (SLP) anomalies over the North Pacific and identifies stronger than normal Pacific High and Aleutian Low pressure systems. Enhanced trans-Pacific transport occurs when this index is positive and is characterized by a stronger than normal meridional pressure gradient and thus by enhanced westerly flow over $35-55^{\circ} \mathrm{N}$ in the central North Pacific. In contrast, reduced trans-Pacific transport is characterized by a weaker than normal contrast between the Aleutian Low and Pacific High (and thus a weaker westerly flow) and a jet confined within the northwest Pacific. Liang et al. (2005) found that their LRT3 index captures $42 \%$ and $55 \%$ of the monthly and interannual variance in trans-Pacific transport, respectively. It was developed to better understand 
the ALRT of CO, a relatively long-lived species, but it is relevant to shorter-lived species such as $\mathrm{NO}_{\mathrm{x}}$ since the timescales involved are monthly/seasonal averages.

Table 5 presents mean LRT3 index values (data provided by Q. Liang) calculated from daily (left column, includes $\pm 1 \sigma$ ) and monthly (right two columns) SLP anomalies. For the range of dates of interest to our analysis (15 April-20 May), the left column of Table 5 illustrates that 2009 shows a consistently more negative LRT3 index value than 2007 or 2008. Since the LRT3 index was developed to investigate changes on a longer temporal scale (i.e., monthly SLP anomalies, not daily SLP anomalies), we include monthly LRT3 index values in the other two columns of Table 5. Again, we see that 2009 is the only year of the three that has negative LRT3 values for both April and May. This data corroborates our conclusion from the NCEP meteorological analyses (Fig. 8) that spring 2009 experienced less ALRT than spring 2007 or 2008.

\subsection{Characterization of the top 20 FT NO $\mathrm{NO}_{\mathrm{x}}$ events observed at MBO}

Using the criteria for identifying FT air described in Sect. 3.2, we have identified the top 20 springtime, clearsky, FT $\mathrm{NO}_{\mathrm{x}}$ events at MBO by ranking them in terms of their magnitude (pptv) and duration (h). For each of these 20 events, we used HYSPLIT backtrajectory calculations, as well as $\mathrm{NO}_{\mathrm{x}} / \mathrm{CO}$ and TAM/CO correlations (where $\mathrm{TAM}=$ Total Airborne Mercury $=$ gaseous elemental $\mathrm{Hg}+$ particulate-bound $\mathrm{Hg}+$ gaseous oxidized $\mathrm{Hg}$ ) to determine a probable source region for the $\mathrm{NO}_{\mathrm{x}}$ observed at $\mathrm{MBO}$ (Table 6). Slopes of the trace gas relationships were determined using hourly data from $4 \mathrm{~h}$ prior through $4 \mathrm{~h}$ after an event. This analysis revealed two broad classifications of events: "Imported" or "North American". (Example backtrajectories for a selected event in each classification are shown in Supplemental Fig. 2.) Ten events fall in the former category and five in the latter; three yielded backtrajectories that led to an inconclusive assignment in probable source region and two indicated a mix of air from both regions.

Most events $(n=13)$ either did not have a statistically significant TAM/CO correlation $(p<0.05)$ or $\mathrm{Hg}$ data was unavailable. Weiss-Penzias et al. (2007) calculate a statistically significant TAM/CO slope of $0.0046 \pm 0.0013 \mathrm{ng} / \mathrm{m}^{3} / \mathrm{ppbv}$ for 10 ALRT events at MBO from 2004-05. However, our analysis reveals that this ratio varies greatly with no consistent pattern for plumes we attribute to either "Imported" or "North American" based on our backtrajectory analysis. If the $\mathrm{NO}_{\mathrm{x}} / \mathrm{CO}$ slope is large, it is indicative of a concentrated $\mathrm{NO}_{\mathrm{x}}$ plume and, therefore, is most likely to be from regional (i.e., "North American") sources. This is supported by the one plume we are certain is from this source region: 22 April 2007. In contrast, "Imported" plumes either show no significant $\mathrm{NO}_{\mathrm{x}} / \mathrm{CO}$ correlation or a far lower value than those from a North American source. Plumes in which there is
Table 5. (left) Springtime (15 April-20 May) mean $\pm 1 \sigma$ LRT3 index (Liang et al., 2005) averaged from daily values and (right) monthly mean LRT3 values for both April and May from 2007-09.

\begin{tabular}{lrrr}
\hline LRT3 & 15 April-20 May & April & May \\
\hline 2007 & $0.31 \pm 1.67$ & 1.69 & -0.25 \\
2008 & $-0.38 \pm 2.26$ & -1.18 & 0.28 \\
2009 & $-1.27 \pm 1.43$ & -0.98 & -1.01 \\
\hline
\end{tabular}

substantial subsidence (classified as "Imported" in Table 6) quite often (seven out of ten cases) have no significant correlation between $\mathrm{NO}_{\mathrm{x}}$ and $\mathrm{CO}$, suggesting that these events are decomposition of background PAN in the FT as opposed to the subsidence of a concentrated Asian plume.

To characterize conditions conducive to delivering high $\mathrm{NO}_{\mathrm{x}}$ in FT air, we examined meteorological data (NCEP reanalysis data) for the date two days prior to each event at MBO (to allow time for transport to the site). These results are shown in Fig. 9. The left column shows the FT synoptic conditions (geopotential heights, air temperature, vector winds and vertical velocity) for the 10 Imported events; the right column illustrates the same parameters but for the 5 North American events. We show results for $700 \mathrm{hPa}$, but similar patterns in the anomalies are seen throughout the troposphere $(800 \mathrm{hPa}$ through $500 \mathrm{hPa})$. Distinct differences are seen between the two groups. For the Imported events, anomalously high geopotential heights extend from the Aleutian Islands southeast to Baja California, with a maximum anomaly just off the Oregon coast. As alluded to earlier, these anomalously high geopotential heights (Fig. 9a) are associated with anomalously warm temperatures (Fig. 9b). Figure 9d shows that the coastal USA region experienced anomalously large subsidence rates during these events, as well. This synoptic set-up would support enhanced PAN decomposition relative to the mean state (Fig. 8c).

In contrast, a stark difference in FT synoptic anomalies is observed for the North American events. Remarkably low geopotential heights (Fig. 8e) dominate the eastern-central Pacific and are associated with anomalously cool temperatures throughout the Pacific Northwest region of the US and into the Northeast Pacific (Fig. 8f). These conditions are manifested in all 5 events (i.e., the anomalies presented in the right column of Fig. 8 are not driven by one or two very strong events). The vector wind anomalies (Fig. $8 \mathrm{~g}$ ) illustrate the strength of the cyclonic flow in the east-central Pacific associated with convection (negative vertical velocity anomalies, Fig. 8h). To better understand where the high $\mathrm{NO}_{\mathrm{x}}$ concentrations may be coming from in these events, we ran 5-day forward trajectories from various urban centers in central California (e.g., San Francisco, Sacramento). The results are not shown here, but in 4 of these 5 events forward trajectories from these cities either pass over MBO or flow 
Table 6. Classification using HYSPLIT air mass backtrajectories (using GDAS, NCEP and EDAS meteorological fields) and trace gas ratios from MBO for the top 20 clear-sky, FT NO $\mathrm{NO}_{\mathrm{x}}$ events observed at MBO during spring 2007-2009. NS indicates no significant correlation exists (i.e., p-value was $>0.05$ ) and ND indicates no $\mathrm{Hg}$ data was available. Numbers in parentheses below indicate "Confidence Index".
If $\mathrm{A}>80 \%$, Imported (1)
If $\mathrm{B}>80 \%$, North American (1)
If $\mathrm{A}$ and $\mathrm{B}<50 \%$, Unknown (3)
If $50 \%<\mathrm{A}<80 \%$, Imported (2)
If $50 \%<\mathrm{B}<80 \%$, North American (2)
If $\mathrm{A}$ and $\mathrm{B}>80 \%$, Mix (1)
If $\mathrm{A}<50 \%$, Not Imported
If $\mathrm{B}<50 \%$, Not North American
If $50 \%<\mathrm{A}$ and $\mathrm{B}<80 \%$, Mix (2)

\begin{tabular}{|c|c|c|c|c|c|c|c|}
\hline \multirow[b]{2}{*}{$\begin{array}{l}\text { Event } \\
\text { Rank }\end{array}$} & \multirow{2}{*}{\multicolumn{2}{|c|}{$\begin{array}{l}\text { Ranking Criteria } \\
\text { Datetime, PDT (UTC - 07:00 h) }\end{array}$}} & \multirow[b]{2}{*}{$\begin{array}{l}\text { Slope }\left(R^{2}\right) \text { of } \\
\mathrm{NO}_{\mathrm{x}} \text { vs. CO } \\
\text { relationship } \\
\text { during event, } \\
\text { in pptv/ppbv }\end{array}$} & \multirow[b]{2}{*}{$\begin{array}{l}\text { Slope }\left(R^{2}\right) \text { of } \\
\text { TAM vs. CO } \\
\text { relationship } \\
\text { during event, } \\
\text { in } \mathrm{ng} / \mathrm{m}^{3} / \mathrm{ppbv}\end{array}$} & \multicolumn{2}{|c|}{$\begin{array}{c}\text { Backtrajectory Analysis } \\
\% \text { of trajectories satisfying the criterion }\end{array}$} & \multirow[b]{2}{*}{$\begin{array}{c}\text { Classification of } \\
\text { Pollution Plume } \\
\text { (Confidence Index) } \\
1=\text { Certain } \\
2=\text { Best guess } \\
3=\text { Unknown }\end{array}$} \\
\hline & & & & & $\begin{array}{l}\text { Is there subsidence } \\
\geq 100 \mathrm{hPa} \text { on the } \\
\text { approach (within } 72 \mathrm{~h} \text { ) } \\
\text { to MBO? }\end{array}$ & $\begin{array}{c}\mathrm{B} \\
\text { Do the backtrajectories } \\
\text { spend time in the } \mathrm{BL} \\
(>850 \mathrm{hPa}) \text { on the } \\
\text { approach (within } 72 \mathrm{~h}) \\
\text { to } \mathrm{MBO} \text { ? }\end{array}$ & \\
\hline 1 & $271 \pm 87$ & 4/24/2009, 00:00-08:00 & NS & ND & $100 \%$ & $0 \%$ & Imported (1) \\
\hline 2 & $280 \pm 86$ & 4/22/2007, 00:00-06:00 & $29.63(0.43)$ & NS & $0 \%$ & $100 \%$ & North American (1) \\
\hline 3 & $253 \pm 67$ & 4/28/2009, 00:00-04:00 & $17.03(0.63)$ & ND & $93 \%$ & $100 \%$ & $\operatorname{Mix}(1)$ \\
\hline 4 & $235 \pm 87$ & 4/15/2009, 00:00-04:00 & $21.97(0.36)$ & ND & $11 \%$ & $48 \%$ & Unknown (3) \\
\hline 5 & $186 \pm 17$ & 4/25/2007, 00:00-08:00 & NS & $-0.0056(0.46)$ & $96 \%$ & $19 \%$ & Imported (1) \\
\hline 6 & $189 \pm 14$ & 5/16/2007, 00:00-07:00 & NS & NS & $74 \%$ & $67 \%$ & $\operatorname{Mix}(2)$ \\
\hline 7 & $193 \pm 40$ & 5/10/2007, 00:00-04:00 & $4.22(0.41)$ & $0.0058(0.56)$ & $22 \%$ & $44 \%$ & Unknown (3) \\
\hline 8 & $165 \pm 30$ & 4/27/2008, 00:00-08:00 & $1.93(0.51)$ & NS & $19 \%$ & $0 \%$ & Unknown (3) \\
\hline 9 & $166 \pm 47$ & 5/2/2008, 00:00-07:00 & $9.52(0.28)$ & $-0.0117(0.70)$ & $81 \%$ & $11 \%$ & Imported (1) \\
\hline 10 & $171 \pm 16$ & 5/2/2009, 00:00-05:00 & $-4.27(0.63)$ & $0.0069(0.88)$ & $0 \%$ & $74 \%$ & North American (2) \\
\hline 11 & $152 \pm 6$ & 4/22/2008, 00:00-08:00 & NS & NS & $0 \%$ & $78 \%$ & North American (2) \\
\hline 12 & $145 \pm 6$ & 5/15/2007, 00:00-07:00 & $4.03(0.42)$ & NS & $100 \%$ & $0 \%$ & Imported (1) \\
\hline 13 & $149 \pm 30$ & 4/19/2007, 00:00-06:00 & NS & NS & $100 \%$ & $0 \%$ & Imported (1) \\
\hline 14 & $141 \pm 29$ & 5/3/2008, 00:00-07:00 & NS & NS & $96 \%$ & $7 \%$ & Imported (1) \\
\hline 15 & $139 \pm 17$ & 5/4/2008, 00:00-07:00 & NS & $0.0052(0.54)$ & $70 \%$ & $15 \%$ & Imported (2) \\
\hline 16 & $157 \pm 24$ & 4/17/2007, 00:00-04:00 & NS & NS & $93 \%$ & $19 \%$ & Imported (1) \\
\hline 17 & $190 \pm 40$ & 5/19/2007, 00:00-03:00 & NS & NS & $7 \%$ & $70 \%$ & North American (2) \\
\hline 18 & $194 \pm 21$ & 4/25/2008, 00:00-02:00 & NS & $0.0017(0.81)$ & $67 \%$ & $0 \%$ & Imported (2) \\
\hline 19 & $183 \pm 31$ & 5/2/2007, 00:00-02:00 & $-6.55(0.56)$ & $0.0041(0.53)$ & $0 \%$ & $78 \%$ & North American (2) \\
\hline 20 & $182 \pm 41$ & 4/27/2009, 00:00-02:00 & $10.47(0.52)$ & ND & $100 \%$ & $0 \%$ & Imported (1) \\
\hline
\end{tabular}

into this off-shore region of cyclonic flow. Once air is in this strong low-pressure center off the coast, trajectories cannot resolve their pathways further. However, it is probable that this air was subsequently brought ashore as the low center and its accompanying fronts traveled eastward.

These analyses show that large $\mathrm{FT} \mathrm{NO}_{\mathrm{x}}$ concentrations at MBO are not limited to the long-range transport of Asian pollution. Despite being $<200 \mathrm{~km}$ from the coast with no large industrial facilities or urban centers between $\mathrm{MBO}$ and the coast, our site is still influenced from North American emissions - even during times when we believe to be sampling FT air (i.e., dry, overnight periods). In several cases, it seems quite likely that the high $\mathrm{FT} \mathrm{NO}_{\mathrm{x}}$ mixing ratios observed at MBO appear to be some mix of Asian and continental North American emissions. Furthermore, even without an influence from concentrated pollution plumes, we observe elevated $\mathrm{NO}_{\mathrm{x}}$ due to the subsidence of FT air, facilitating the decomposition of background PAN. We cannot rule out entirely the possibility that $\mathrm{NO}_{\mathrm{x}}$ emitted from snowpack (Honrath et al., 2000, 2002; Dominé and Shepson, 2002; Davis et al., 2004) on Mt. Bachelor and nearby snow-covered regions contributes to high $\mathrm{NO}_{\mathrm{x}}$ mixing ratios observed at MBO. However, this is an unlikely contributor to the $\mathrm{FT} \mathrm{NO}_{\mathrm{x}}$ events analyzed here because: (a) there is minimal correlation between wind speeds and $\mathrm{NO}_{\mathrm{x}}$, and (b) the process of releasing $\mathrm{NO}_{\mathrm{x}}$ from snow requires sunlight (Honrath et al., 2000) and these events all occurred overnight.

\section{Summary and conclusions}

We present $\mathrm{NO}_{\mathrm{x}}$ observations from $\mathrm{MBO}$ from one autumn (18 August-9 October2008) and three spring (15 April-20 May) campaigns. The performance of our custom-made $\mathrm{NO}_{\mathrm{x}}$ chemiluminescence instrument along with the newlydeveloped $\mathrm{NO}_{2}$ Blue Light Converter was shown to be consistent and acceptable for all campaigns (Supplemental Fig. 1). We summarized a variety of previous efforts at isolating FT air at mountaintop sites and present results from our own novel experiment involving "chairlift soundings" (Fig. 1). Analysis of this data (Figs. 4, 5 and Table 2) suggests that the onset of a BL influence at the summit of MBO on cloud-free days during spring 2008 occurred between $\sim 10: 00-10: 30$ PDT. As a result, we segregated our $\mathrm{NO}_{\mathrm{x}}$ data by a time-of-day criterion (Table 1) that termed "night" (i.e., FT) air as that being sampled between $5 \mathrm{~h}$ 

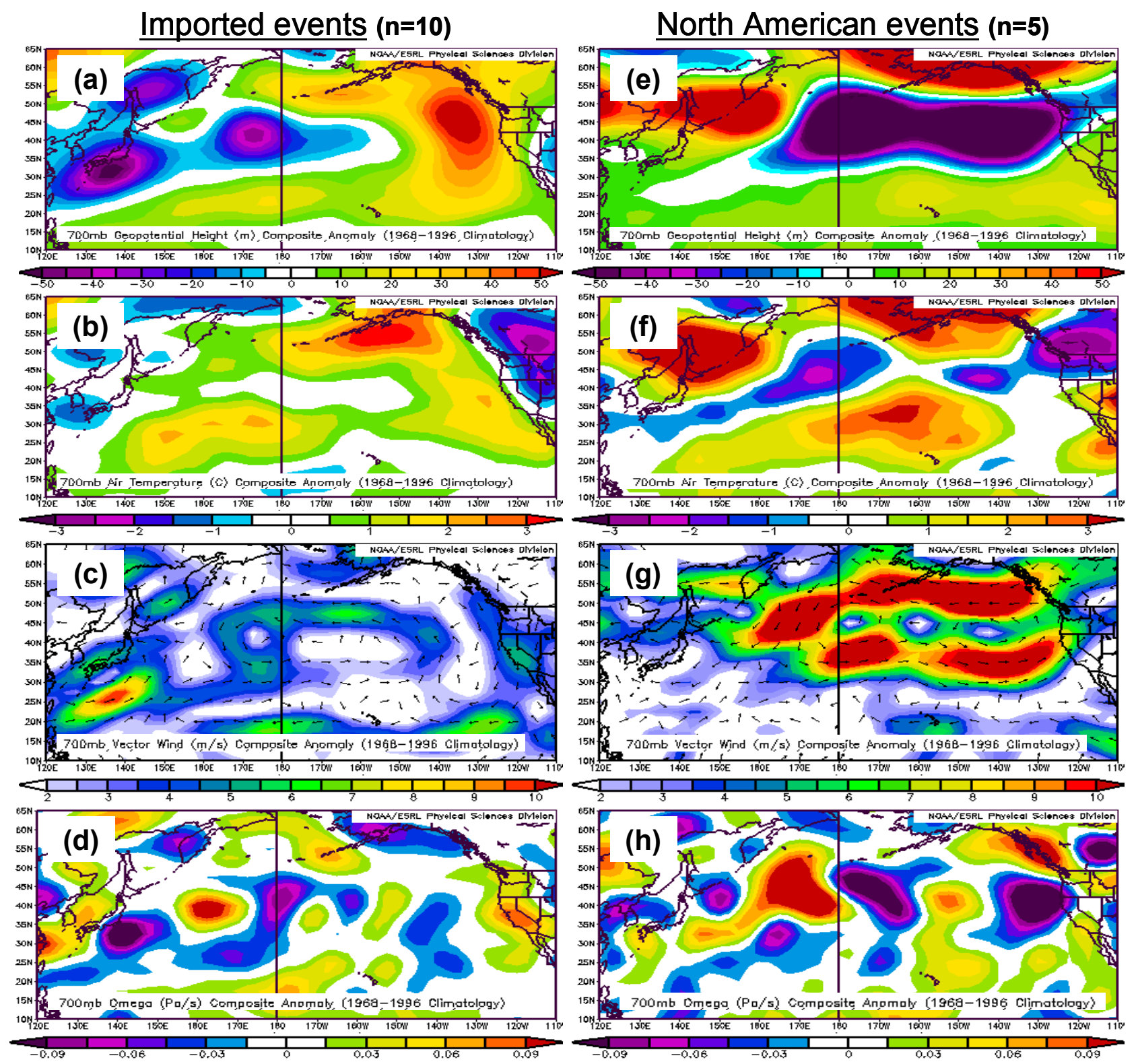

Fig. 9. Anomalies in geopotential height $(\mathbf{a}, \mathbf{e})$, air temperature $(\mathbf{b}, \mathbf{f})$, vector winds $(\mathbf{c}, \mathbf{g})$ and vertical velocity $(\mathbf{d}, \mathbf{h})$ at $700 \mathrm{hPa}(\mathrm{from} \mathrm{NCEP}$ reanalysis) for the top 20 clear-sky, FT NO x events at MBO whose backtrajectory analysis allowed a classification of "Imported" (a-d) vs. "North American" (e-h).

after sunset through $1 \mathrm{~h}$ after sunrise and "day" (i.e., BLinfluenced) air as that being sampled between $5 \mathrm{~h}$ after sunrise through $1 \mathrm{~h}$ after sunset. Segregating the $\mathrm{NO}_{\mathrm{x}}$ data this way revealed starker contrasts than segregation using specific humidity.

Using this time-of-day criterion, median $\mathrm{NO}_{\mathrm{x}}$ mixing ratios in the FT at MBO range from 55-100 pptv (Fig. 3). These concentrations are lower than other continental mountain sites (Fig. 6, Table 3b). This is likely due to the fact that $\mathrm{MBO}$ is far-removed from any major regional $\mathrm{NO}_{\mathrm{x}}$ sources, whereas most other continental mountaintop sites are directly influenced by regional anthropogenic activity. Mean $\mathrm{FT} \mathrm{NO}_{\mathrm{x}}$ mixing ratios at $\mathrm{MBO}$ are comparable to values collected aboard aircraft in the eastern Pacific (Fig. 6, Table 3a). These mean $\mathrm{NO}_{\mathrm{x}}$ mixing ratios are slightly greater than those in the central Pacific, which is likely due to $\mathrm{NO}_{\mathrm{x}}$ being released from PAN decomposition in the climatological region of subsidence off the west coast of North America. The distribution of $\mathrm{NO}_{\mathrm{x}}$ data at $\mathrm{MBO}$ (Fig. 2) is different during autumn $(175 \pm 548 \mathrm{pptv})$ than during the spring campaigns due to regional wildfires causing prolonged periods of very large $\mathrm{NO}_{\mathrm{x}}$ enhancements. 
We presented a synoptic climatology for the FT over the Asia-Pacific-North America region (Fig. 7) and explained how this impacts $\mathrm{NO}_{\mathrm{x}}$ observations at $\mathrm{MBO}$. We detected a significant decline in the mean $\mathrm{NO}_{\mathrm{x}}$ mixing ratio from spring 2007 and 2008 to spring 2009. We showed that this decline was coincident with anomalously high FT geopotential heights over the North Pacific, anomalously weak westerly flow (about half what it typically is) in the FT over the central Pacific (Fig. 8) and negative LRT3 values (Table 5) indicating a reduction in ALRT. We hypothesize that these meteorological anomalies may have facilitated an earlier release of $\mathrm{NO}_{\mathrm{x}}$ from PAN decomposition and enhanced dispersion of $\mathrm{NO}_{\mathrm{x}}$ during trans-Pacific transport, respectively. To fully test this hypothesis, the non-trivial task of collecting a temperature "history" along all backtrajectories originating at $\mathrm{MBO}$ is needed. We plan to continue this investigation into the cause(s) of interannual variability in the future as we better characterize PAN interannual variability at MBO and compile a complete backtrajectory database.

Finally, we identified the top 20 clear-sky, FT NO $\mathrm{N}_{\mathrm{x}}$ events at MBO using the time-of-day segregation described earlier. For each of these 20 events we used HYSPLIT backtrajectories and trace gas observations from MBO to determine a probable source region for the enhanced $\mathrm{NO}_{\mathrm{x}}$ seen at our site (Table 6). Half $(n=10)$ of the events were termed "Imported", while 5 others were found to have a North American influence. To further understand what synoptic regimes are conducive to delivering large $\mathrm{NO}_{\mathrm{x}}$ mixing ratios in these instances, we examined NCEP reanalysis and found distinctly different patterns in FT geopotential heights, temperatures, vector winds and vertical velocities (Fig. 9). Imported events are most likely to occur when the following synoptic conditions in the FT are met: (1) anomalously high geopotential heights extending from the Aleutian Islands to Baja California (2) anomalously warm temperatures throughout the Northeast-East Pacific and (3) enhanced subsidence over the entire western USA extending into the Pacific. Events with a North American influence occur when there is very strong cyclonic flow associated with low geopotential heights, cool temperatures and lifting of air in the east-central Pacific. Thus, it is possible that the recirculation of pollution emitted from the North American continent can affect air quality in remote regions.

Understanding $\mathrm{NO}_{\mathrm{x}}$ (and the associated $\mathrm{PAN}-\mathrm{NO}_{\mathrm{y}}-\mathrm{O}_{3}$ ) chemistry in the Northeast Pacific is essential if we are to better understand $\mathrm{O}_{3}$ production from long-range transport in this region (Fiore et al., 2009; Reidmiller et al., 2009a; Cooper et al., 2010). Here we show that while ALRT events certainly deliver high $\mathrm{NO}_{x}$ periods (facilitating $\mathrm{O}_{3}$ production) during spring, subsidence of background air can also create $\mathrm{NO}_{\mathrm{x}}$ enhancements at MBO. Furthermore, we show that continental influences (including off-shore recirculation) can still play a large role at a remote site such as $\mathrm{MBO}$, which is $<200 \mathrm{~km}$ from the Pacific coast. We highlight the important role pollution "events" can play in outweighing impacts when averaged over an entire season. In other words, it is necessary to understand the daily- to weekly- variability of pollution transport, rather than merely investigating drivers of monthly or seasonal averages. Further exploration of specific periods of $\mathrm{NO}_{\mathrm{x}}, \mathrm{PAN}$ and $\mathrm{O}_{3}$ enhancements along the western North America coast is critical if we are to better plan and prepare for the impact from increasing Asian emissions and the effects a changing climate may have on air quality in this region.

\section{Supplementary material related to this article is available online at: http://www.atmos-chem-phys.net/10/6043/2010/ acp-10-6043-2010-supplement.zip.}

Acknowledgements. Support for David R. Reidmiller and the Mt. Bachelor Observatory was provided by the National Science Foundation under Grant ATM-0724327. We also wish to extend our gratitude to the Mt. Bachelor Ski Resort Lift Maintenance Staff. Q. Liang kindly provided the LRT3 index data.

Edited by: L. Carpenter

\section{References}

Balzani Lööv, J. M., Henne, S., Legreid, G., Staehelin, J., Reimann, S., Prévôt, Steinbacher, M., and Vollmer, M. K.: Estimation of background concentrations of trace gases at the Swiss Alpine site Jungfaujoch (3580 m a.s.1.), J. Geophys. Res., 113, D22305, doi:10.1029/2007JD009751, 2008.

Berg, L. K. and Stull, R. B.: Parameterization of joint frequency distributions of potential temperature and water vapor mixing ratio in the daytime convective boundary layer, J. Atmos. Sci., 61(7), 813-828, 2004.

Bertram, T. H.: Observation-based Constraints for the Source Strengths, Transport and Partitioning of Reactive Nitrogen on Regional and Global Scales, PhD dissertation, Department of Chemistry, University of California - Berkeley, December 2006.

Brasseur, G. P., Orlando, J. J., and Tyndall, G. S.: Atmospheric Chemistry and Global Change, Oxford University Press, New York, 654 pp., 1999.

Buhr, M.: Measurement of $\mathrm{NO}_{2}$ in Ambient Air Using a SolidState Photolytic Converter, Paper number 78, Sonoma Technology, Inc., Petaluma, California, USA, 2004.

Carpenter, L. J., Green, T. J., Mills, G. P., Bauguitte, S., Penkett, S. A., Zanis, P., Schuepbach, E., Schmidbauer, N., Monks, P. S., and Zellweger, C.: Oxidized nitrogen and ozone production efficiencies in the springtime free troposphere over the Alps, J. Geophys. Res., 105(D11), 14547-14559, 2000.

Carroll, M., McFarland, M., Ridley, B. A., and Albritton, D. L.: Ground-based nitric oxide measurements at Wallops Island, Virginia, J. Geophys. Res., 90, 12853-12860, 1985.

Chameides, W. L., Davis, D. D., Gregory, G. L., Sachse, G., and Torres, A. L.: Ozone precursors and ozone photochemistry over eastern North Pacific during the spring of 1984 based on the NASA GTE/CITE-1 airborne observations, J. Geophys. Res., 94(D7), 9799-9808, 1989. 
Chameides, W. L., Davis, D. D., Bradshaw, J., Sandholm, S., Rodgers, M., Baum, B., Ridley, B., Madronich, S., Carroll, M. A., Gregory, G., Schiff, H. I., Hastie, D. R., Torres, A., and Condon, E.: Observed and model-calculated $\mathrm{NO}_{2} / \mathrm{NO}$ ratios in tropospheric air sampled during the NASA GTE/CITE-2 field study, J. Geophys. Res., 95(D7), 10235-10247, 1990.

Cooper, O., Parrish, D. D., Stohl, A., Trainer, M., Nédélec, P., Thouret, V., Cammas, J. P., Oltmans, S. J., Johnson, B. J., Tarasick, D., Leblanc, T., McDermid, I. S., Jaffe, D., Gao, R., Stith, J., Ryerson, T., Aikin, K., Campos, T., Weinheimer, A., and Avery, M. A.: Increasing springtime ozone mixing ratios in the free troposphere over western North America, Nature, 463, 344-348, doi:10.1038/nature08708, 2010.

Davis, D. D., Bradshaw, J. D., Rodgers, M. O., Sandholm, S. T., and KeSheng, S.: Free tropospheric and boundary layer measurements of NO over the central and eastern North Pacific Ocean, J. Geophys. Res., 92(D2), 2049-2070, 1987.

Davis, D., Chen, G., Buhr, M., Crawford, J., Lenschow, D., Lefer, B., Shetter, R., Eisele, F., Mauldin, L., and Hogan, A.: South Pole $\mathrm{NO}_{\mathrm{x}}$ chemistry: an assessment of factors controlling variability and absolute values, Atmos. Environ., 38, 5375-5388, 2004.

Delmas, R., Serça, D., and Jambert, C.: Global inventory of $\mathrm{NO}_{\mathrm{x}}$ sources, Nutr. Cycl. Agroecosys., 48, 51-60, 1997.

Dominé, F. and Shepson, P. B.: Air-snow interactions and atmospheric chemistry, Science, 297, 1506-1510, 2002.

Draxler, R. R. and Hess, G. D.: An overview of the HYSPLIT4 modelling system for trajectories, dispersion, and deposition, Aust. Meteorol. Mag., 47, 295-308, 1998.

Draxler, R. R. and Rolph, G. D.: HYSPLIT (HYbrid Single-Particle Lagrangian Integrated Trajectory) Model access via NOAA ARL READY web site, NOAA Air Resources Laboratory, Silver Spring, MD, 2003, available online at: http://www.arl.noaa.gov/ ready/hysplit4.html, last access: December 2009.

Drummond, J., Volz, A., and Ehhalt, D. H.: An optimized chemiluminescence detector for tropospheric NO measurements, J. Atmos. Chem., 2, 287-306, 1985.

Emmons, L. K., Pfister, G. G., Edwards, D. P., Gille, J. C., Sachse, G., Blake, D., Wofsy, S., Gerbig, C., Matross, D., and Nédélec, P.: Measurements of Pollution in the Troposphere (MOPITT) validation exercises during summer 2004 field campaigns over North America, J. Geophys. Res., 112, D12S02, doi:10.1029/2006JD007833, 2007.

Fahey, D. W., Hübler, G., Parrish, D. D., Williams, E. J., Norton, R. B., Ridley, B. A., Singh, H. B., Liu, S. C., and Fehsenfeld, F. C.: Reactive nitrogen species in the troposphere: Measurements of $\mathrm{NO}, \mathrm{NO}_{2}, \mathrm{HNO}_{3}$, particulate nitrate, peroxyacetyl nitrate $(\mathrm{PAN}), \mathrm{O}_{3}$, ad total reactive odd nitrogen $\left(\mathrm{NO}_{\mathrm{y}}\right)$ at Niwot Ridge, Colorado, J. Geophys. Res., 91(D9), 9781-9793, 1986.

Finley, B. D., Swartzendruber, P. C., and Jaffe, D. A.: Particulate mercury emissions in regional wildfire plumes observed at the Mount Bachelor Observatory, Atmos. Environ., 43, 6074-6083, doi:10.1016/j.atmosenv.2009.08.046, 2009.

Fiore, A. M., Dentener, F. J., Wild, O., Cuvelier, C., Schultz, M. G., Hess, P., Textor, C., Schulz, M., Doherty, R. M., Horowitz, L. W., MacKenzie, I. A., Sanderson, M. G., Shindell, D. T., Stevenson, D. S., Szopa, S., Van Dingenen, R., Zeng, G., Atherton, C., Bergmann, D., Bey, I., Carmichael, G., Collins, W. J., Duncan, B. N., Faluvegi, G., Folberth, G., Gauss, M., Gong, S., Hauglus- taine, D., Holloway, T., Isaksen, I. S. A., Jacob, D. J., Jonson, J. E., Kaminski, J. W., Keating, T. J., Lupu, A., Marmer, E., Montanaro, V., Park, R. J., Pitari, G., Pringle, K. J., Pyle, J. A., Schroeder, S., Vivanco, M. G., Wind, P., Wojcik, G., Wu, S., and Zuber, A.: Multi-model estimates of intercontinental sourcereceptor relationships for ozone pollution, J. Geophys. Res., 114, D04301, doi:10.1029/2008JD010816, 2009.

Fischer, E. V., Jaffe, D. A., Reidmiller, D. R., and Jaeglé, L.: Meteorological controls on observed peroxyacetyl nitrate (PAN) at Mount Bachelor during the spring of 2008, J. Geophys. Res., 115, D03302, doi:10.1029/20092009JD012776, 2010.

Fischer, E. V., Jaffe, D. A., Marley, N. A., Gaffney, J. S., and Marchany-Rivera, A.: Optical properties of aged Asian aerosols observed over the U.S. Pacific Northwest, J. Geophys. Res., 115, D03302, doi:10.1029/2009JD012776, 2010.

Forrer, J., Rüttimann, R., Schneiter, D., Fischer, A., Buchmann, B., and Hofer, P.: Variability of trace gases at the high-Alpine site Jungfraujoch caused by meteorological transport processes, J. Geophys. Res., 105(D10), 12241-12251, 2000.

Honrath, R. E., Peterson, M. C., Dziobak, M. P., Dibb, J. E., Arsenault, M. A., and Green, S. A.: Release of $\mathrm{NO}_{\mathrm{x}}$ from sunlightirradiated midlatitude snow, Geophys. Res. Lett., 27(15), 22372240, 2000.

Honrath, R. E., Lu, Y., Peterson, M. C., Dibb, J. E., Arsenault, M. A., Cullen, N. J., and Steffen, K.: Vertical fluxes of $\mathrm{NO}_{\mathrm{x}}, \mathrm{HON}$, and $\mathrm{HNO}_{3}$ above the snowpack at Summit, Greenland, Atmos. Environ., 36, 2629-2640, 2002.

Hudman, R., Jacob, D. J., Cooper, O. R., Evans, M. J., Heald, C. L., Park, R. J., Fehsenfeld, F., Flocke, F., Holloway, J., Hübler, G., Kita, K., Koike, M., Kondo, Y., Neuman, A., Nowak, J., Oltmans, S., Parrish, D., Roberts, J. M., and Ryerson, T.: Ozone production in transpacific Asian pollution plumes and implications for ozone air quality in California, J. Geophys. Res., 109, D23S10, doi:10.1029/2004JD004974, 2004.

Jaffe, D., Anderson, T., Covert, D., Kotchenruther, R., Trost, B., Danielson, J., Simpson, W., Berntsen, T., Karlsdottir, S., Blake, D., Harris, J., Carmichael, G., and Uno, I.: Transport of Asian air pollution to North America, Geophys. Res. Lett., 26(6), 711714, 1999.

Jaffe, D. A., Prestbo, E., Swartzendruber, P., Weiss-Penzias, P., Kato, S., Takami, A., Hatakeyama, S., and Kajii, Y.: Export of atmospheric mercury from Asia, Atmos. Environ., 39, 3029-3038, 2005.

Keith, L. H.: Report results right!, Chemtech, 486-489, 1991.

Kleissl, J., Honrath, R. E., Dziobak, M. P., Tanner, D., Val Martin, R., Owen, R. C., and Helmig, D.: Occurrence of upslope flows at the Pico mountaintop observatory: A case study of orographic flows on a small, volcanic island, J. Geophys. Res., 112, D10S35, doi:10.1029/2006JD007565, 2007.

Koike, M., Kondo, Y., Kawakami, S., Singh, H. B., Ziereis, H., and Merrill, J. T.: Ratios of reactive nitrogen species over the Pacific during PEM-West A, J. Geophys. Res., 101(D1), 18291851, 1996.

Koike, M., Kondo, Y., Kita, K., Takegawa, N., Masui, Y., Miyazaki, Y., Ko, M. W., Weinheimer, A. J., Flocke, F., Weber, R. J., Thornton, D. C., Sachse, G. W., Vay, S. A., Blake, D. R., Streets, D. G., Eisele, F. L., Sandholm, S. T., Singh, H. B., and Talbot, R. W.: Export of anthropogenic reactive nitrogen and sulfur compounds from the East Asia region in spring, J. Geophys. Res., 108(D20), 
8789, doi:10.1029/2002JD003284, 2003.

Kondo, Y., Koike, M., Kawakami, S., Singh, H. B., Nakajima, H., Gregory, G. L., Blake, D. R., Sachse, G. W., Merrill, J. T., and Newell, R. E.: Profiles and partitioning of reactive nitrogen over the Pacific Ocean in winter and early spring, J. Geophys. Res., 102(D23), 28405-28424, 1997.

Kotchenruther, R. A., Jaffe, D. A., and Jaeglé, L.: Ozone photochemistry and the role of peroxyacetyl nitrate in the springtime northeastern Pacific troposphere: Results from the Photochemical Ozone Budget of the Eastern North Pacific Atmosphere (PHOBEA) campaign, J. Geophys. Res., 106(D22), 2873128742, 2001a.

Kotchenruther, R. A., Jaffe, D. A., Beine, H. J., Anderson, T. A., Bottenheim, J. W., Harris, J. M., Blake, D. R., and Schmitt, R.: Observations of ozone and related species in the northeast Pacific during the PHOBEA campaigns: 2. Airborne observations, J. Geophys. Res., 106(D7), 7463-7483, 2001b.

Lee, J. D., Moller, S. J., Read, K. A., Lewis, A. C., Mendes, L., and Carpenter, L. J.: Year round measurements of nitrogen oxides and ozone in the tropical North Atlantic marine boundary layer, J. Geophys. Res., 114, D21302, doi:10.1029/2009JD011878, 2009.

Liang, Q., Jaeglé, L., and Wallace, J. M.: Meteorological indices for Asian outflow and transpacific transport on daily to interannual timescales, J. Geophys. Res., 110, D18308, doi:10.1029/2005JD005788, 2005.

Martin, R. V., Jacob, D. J., Yantosca, R. M., Chin, M., and Ginoux, P.: Global and regional decreases in tropospheric oxidants from photochemical effects of aerosols, J. Geophys. Res., 108(D3), 4097, doi:10.1029/2002JD002622, 2003.

McKendry, I., Strawbridge, K., O’Neill, N., Macdonald, A.-M., Leaitch, R., Jaffe, D., Sharma, S., Sheridan, P., and Ogren, J.: California Wildfire Plumes over Southwestern British Columbia: LIDAR, sunphotometry, and mountain top chemistry observations, to be submitted, Atmos. Chem. Phys. Discuss., 2010.

Miyazaki, Y., Kondo, Y., Koike, M., Fuelberg, H. E., Kiley, C. M., Kita, K., Takegawa, N., Sachse, G. W., Flocke, F., Weinheimer, A. J., Singh, H. B., Eisele, F. L., Zondlo, M., Talbot, R. W., Sandholm, S. T., Avery, M. A., and Blake, D. R.: Synoptic-scale transport of reactive nitrogen over the western Pacific in spring, J. Geophys. Res., 108(D20), 8788, doi:10.1029/2002JD003248, 2003

Murphy, J. G., Day, D. A., Cleary, P. A., Wooldridge, P. J., and Cohen, R. C.: Observations of the diurnal and seasonal trends in nitrogen oxides in the western Sierra Nevada, Atmos. Chem. Phys., 6, 5321-5338, doi:10.5194/acp-6-5321-2006, 2006.

Nakamura, K., Kondo, Y., Chen, G. Crawford, J. H., Takegawa, N., Koike, M., Kita, K., Miyazaki, Y., Shetter, R. E., Lefer, B. L., Avery, M., and Matsumoto, J.: Measurement of $\mathrm{NO}_{2}$ by the photolysis conversion technique during the Transport and Chemical Evolution Over the Pacific (TRACE-P) campaign, J. Geophys. Res., 108(D24), 4752, doi:10.1029/2003JD003712, 2003.

Nowak, J. B., Parrish, D. D., Neuman, J. A., Holloway, J. S., Cooper, O. R., Ryerson, T. B., Nicks, D. K., Flocke, F., Roberts, J. M., Atlas, E., de Gouw, J. A., Donnelly, S., Dunlea, E., Hübler, G. Huey, L. G., Schauffler, S., Tanner, D. J., Warneke, C., and Fehsenfeld, F. C.: Gas-phase chemical characteristics of Asian emission plumes observed during ITCT-2K2 over the eastern North Pacific Ocean, J. Geophys. Res., 109(D23), D23S19, doi:10.1029/2003JD004488, 2004.
Ohara, T., Akimoto, H., Kurokawa, J., Horii, N., Yamaji, K., Yan, X., and Hayasaka, T.: An Asian emission inventory of anthropogenic emission sources for the period 1980-2020, Atmos. Chem. Phys., 7, 4419-4444, doi:10.5194/acp-7-4419-2007, 2007.

Parrish, D. D., Hahn, C. H., Fahey, D. W., Williams, E. J., Bollinger, M. J., Hübler, G., Buhr, M. P., Murphy, P. C., Trainer, M., Hsie, E. Y., Liu, S. C., and Fehsenfeld, F. C.: Systematic variations in the concentration of $\mathrm{NO}_{\mathrm{x}}$ (NO plus $\mathrm{NO}_{2}$ ) at Niwot Ridge, Colorado, J. Geophys. Res., 95(D2), 1817-1836, 1990.

Reidmiller, D. R., Fiore, A. M., Jaffe, D. A., Bergmann, D., Cuvelier, C., Dentener, F. J., Duncan, B. N., Folberth, G., Gauss, M., Gong, S., Hess, P., Jonson, J. E., Keating, T., Lupu, A., Marmer, E., Park, R., Schultz, M. G., Shindell, D. T., Szopa, S., Vivanco, M. G., Wild, O., and Zuber, A.: The influence of foreign vs. North American emissions on surface ozone in the US, Atmos. Chem. Phys., 9, 5027-5042, doi:10.5194/acp-9-5027-2009, 2009a.

Reidmiller, D. R., Jaffe, D. A., Chand, D., Strode, S., Swartzendruber, P., Wolfe, G. M., and Thornton, J. A.: Interannual variability of long-range transport as seen at the Mt. Bachelor observatory, Atmos. Chem. Phys., 9, 557-572, doi:10.5194/acp-9-557-2009, 2009b.

Reidmiller, D. R.: The long-range transport of Asian pollution: Its variability and impacts on western North America, Ph.D. Dissertation, Department of Atmospheric Sciences, University of Washington, 2010.

Richter, A., Burrows, J. P., Nüß, Granier, C., and Niemeier, U.: Increase in tropospheric nitrogen dioxide over China observed from space, Nature, 437, 557-572, 2009.

Ridley, B. A., Carroll, M. A., and Gregory, G. L.: Measurements of nitric oxide in the boundary layer and free troposphere over the Pacific Ocean, J. Geophys. Res., 92(D2), 2025-2047, 1987.

Seinfeld, J. H. and Pandis, S. N.: Atmospheric Chemistry and Physics: From Air Pollution to Climate Change, John Wiley \& Sons, Inc., New York, 1326 pp., 1998.

Singh, H. B., Viezee, W., Chen, Y., Thakur, A. N., Kondo, Y., Talbot, R. W., Gregory, G. L., Sachse, G. W., Blake, D. R., Bradshaw, J. D., Wang, Y., and Jacob, D. J.: Latitudinal distribution of reactive nitrogen in the free troposphere over the Pacific Ocean in late winter/early spring, J. Geophys. Res., 103(D21), 2823728246, 1998.

Singh, H. B., Brune, W. H., Crawford, J. H., Flocke, F., and Jacob, D. J.: Chemistry and transport of pollution over the Gulf of Mexico and the Pacific: spring 2006 INTEX-B campaign overview and first results, Atmos. Chem. Phys., 9, 2301-2318, doi:10.5194/acp-9-2301-2009, 2009.

Strode, S., Jaeglé, L., Jaffe, D. A., Swartzendruber, P. C., Selin, N. E., Holmes, C., and Yantosca, R. M.: TransPacific transport of mercury, J. Geophys. Res., 113, D15305, doi:10.1029/2007JD009428, 2008.

Swartzendruber, P. C., Jaffe, D. A., Prestbo, E. M., Weiss-Penzias, P., Selin, N. E., Park, R., Jacob, D. J., Strode, S., and Jaeglé, L.: Observations of reactive gaseous mercury in the free troposphere at the Mount Bachelor Observatory, J. Geophys. Res, 111, D24301, doi:10.1029/2006JD007415, 2006.

Takegawa, N., Kondo, Y., Koike, M., Chen, G., Machida, T., Watai, T., Blake, D. R., Streets, D. G., Woo, J.-H., Carmichael, G. R., Kita, K., Miyazaki, Y., Shirai, T., Liley, J. B., and Ogawa, T.: 
Removal of $\mathrm{NO}_{\mathrm{x}}$ and $\mathrm{NO}_{\mathrm{y}}$ in Asian outflow plumes: Aircraft measurements over the western Pacific in January 2002, J. Geophys. Res., 109, D23S04, doi:10.1029/2004JD004866, 2004.

Talbot, R., Dibb, J., Scheuer, E. Seid, G., Russo, R., Sandholm, S., Tan, D., Singh, H., Blake, D., Blake, N., Atlas, E., Sachse, G., Jordan, C., and Avery, M.: Reactive nitrogen in Asian continental outflow over the western Pacific: Results from the NASA Transport and Chemical Evolution over the Pacific (TRACE-P) airborne mission, J. Geophys. Res., 108(D20), 8803, doi:10.1029/2002JD003129, 2003.

Tang, Y., Carmichael, G. R., Horowitz, L. W., Uno, I., Woo, J.H., Streets, D. G., Dabdub, D., Kurata, G., Sandu, A., Allan, J., Atlas, E., Flocke, F., Huey, L. G., Jakoubek, R. O., Millet, D. B., Quinn, P. K., Roberts, J. M. Worsnop, D. R., Goldstein, A., Donnelly, S., Schauffler, S., Stroud, V., Johnson, K., Avery, M. A., Singh, H. B., and Apel, E. C.: Multiscale simulations of tropospheric chemistry in the eastern Pacific and on the U.S. West Coast during spring 2002, J. Geophys. Res., 109, D23S11, doi:10.1029/2004JD004513, 2004.

Thakur, A. N., Singh, H. B., Mariani, P., Chen, Y., Wang, Y., Jacob, D. J., Brasseur, G., Müller, J.-F., and Lawrence, M.: Distribution of reactive nitrogen species in the remote free troposphere: data and model comparisons, Atmos. Environ., 33, 1403-1422, 1999.

Val Martin, M., Honrath, R. E., Owen, R. C., and Li, Q. B.: Seasonal variation of nitrogen oxides in the central North Atlantic lower free troposphere, J. Geophys. Res., 113, D17307, doi:10.1029/2007JD009688, 2008a.

Val Martin, M., Honrath, R. E., Owen, R. C., and Lapina, K.: Largescale impacts of anthropogenic pollution and boreal wildfires on the nitrogen oxides over the central North Atlantic region, J. Geophys. Res., 113, D17308, doi:10.1029/2007JD009689, 2008b.

van der A, R. J., Eskes, H. J., Boersma, K. F., van Noije, T. P. C., Van Roozendael, M., DeSmedt, I., Peters, D. H. M. U., and Meijer, E. W.: Trends, seasonal variability and dominant $\mathrm{NO}_{\mathrm{x}}$ source derived from a ten year record of $\mathrm{NO}_{2}$ measured from space, $\mathrm{J}$. Geophys. Res., 113, D04302, doi:10.1029/2007JD009021, 2008.

Wang, T., Wong, H. L. A., Tang, J., Ding, A., Wu, W. S., and Zhang, X. C.: On the origin of surface ozone and reactive nitrogen observed at a remote mountain site in the northeastern QinghaiTibetan Plateau, western China, J. Geophys. Res., 111, D08303, doi:10.1029/2005JD006527, 2006.

Weiss-Penzias, P., Jaffe, D. A., Swartzendruber, P., Dennison, J. B., Chand, D., Hafner, W., and Prestbo, E.: Observations of Asian air pollution in the free troposphere at Mt. Bachelor Observatory in the spring of 2004, J. Geophys. Res., 110, D10304, doi:10.1029/2005JD006522, 2006.
Weiss-Penzias, P., Jaffe, D. A., Swartzendruber, P., Hafner, W., Chand, D., and Prestbo, E.: Quantifying Asian biomass burning sources of mercury using the $\mathrm{Hg} / \mathrm{CO}$ ratio in pollution plumes observed at the Mount Bachelor Observatory, Atmos. Environ., 41, 4366-4379, 2007.

Winefordener, J. D. and Long, G. L.: Limit of detection, Anal. Chem, 55(7), 712A-724A, 1983.

Wolfe, G. M., Thornton, J. A., McNeill, V. F., Jaffe, D. A., Reidmiller, D., Chand, D., Smith, J., Swartzendruber, P., Flocke, F., and Zheng, W.: Influence of trans-Pacific pollution transport on acyl peroxy nitrate abundances and speciation at Mount Bachelor Observatory during INTEX-B, Atmos. Chem. Phys., 7, 53095325, doi:10.5194/acp-7-5309-2007, 2007.

Zanis, P., Monks, P. S., Schuepbach, E., Carpenter, L. J., Green, T. J., Mills, G. P., Bauguitte, S., and Penkett, S. A.: In situ ozone production under free tropospheric conditions during FREETEX '98 in the Swiss Alps, J. Geophys. Res., 105(D19), 2422324234, 2000.

Zellweger, C., Ammann, M., Buchmann, B., Hofer, P., Lugauer, M., Rüttimann, R., Streit, N., Weingartner, E., and Baltensperger, U.: Summertime $\mathrm{NO}_{\mathrm{y}}$ speciation at the Jungfraujoch, $3580 \mathrm{~m}$ above sea level, Switzerland, J. Geophys. Res., 105(D5), 6655-6667, 2000.

Zellweger, C., Forrer, J., Hofer, P., Nyeki, S., Schwarzenbach, B., Weingartner, E., Ammann, M., and Baltensperger, U.: Partitioning of reactive nitrogen $\left(\mathrm{NO}_{\mathrm{y}}\right)$ and dependence on meteorological conditions in the lower free troposphere, Atmos. Chem. Phys., 3, 779-796, doi:10.5194/acp-3-779-2003, 2003.

Zhang, L., Jacob, D. J., Boersma, K. F., Jaffe, D. A., Olson, J. R., Bowman, K. W., Worden, J. R., Thompson, A. M., Avery, M. A., Cohen, R. C., Dibb, J. E., Flock, F. M., Fuelberg, H. E., Huey, L. G., McMillan, W. W., Singh, H. B., and Weinheimer, A. J.: Transpacific transport of ozone pollution and the effect of recent Asian emission increases on air quality in North America: an integrated analysis using satellite, aircraft, ozonesonde, and surface observations, Atmos. Chem. Phys., 8, 6117-6136, doi:10.5194/acp-8-6117-2008, 2008.

Zhang, L., Jacob, D. J., Kopacz, M., Henze, D. K., Singh, K., and Jaffe, D. A.: Intercontinental source attribution of ozone pollution at western US sites using an adjoint method, Geophys. Res. Lett., 36, L11810, doi:10.1029/2009GL037950, 2009. 